\title{
Photostable Ruthenium(II) Isocyanoborato Luminophores and Their Use in Energy Transfer and Photoredox Catalysis
}

\author{
Lucius Schmid, Christoph Kerzig, Alessandro Prescimone, and Oliver S. Wenger*
}

Cite This: JACS Au 2021, 1, 819-832

Read Online

ABSTRACT: Ruthenium(II) polypyridine complexes are among the most popular sensitizers in photocatalysis, but they face some severe limitations concerning accessible excited-state energies and photostability that could hamper future applications. In this study, the borylation of heteroleptic ruthenium(II) cyanide complexes with $\alpha$-diimine ancillary ligands is identified as a useful concept to elevate the energies of photoactive metal-to-ligand charge-transfer (MLCT) states and to obtain unusually photorobust compounds suitable for thermodynamically challenging energy transfer catalysis as well as oxidative and reductive photoredox catalysis. $\mathrm{B}\left(\mathrm{C}_{6} \mathrm{~F}_{5}\right)_{3}$ groups attached to the $\mathrm{CN}^{-}$ligands stabilize the metalbased $\mathrm{t}_{2 \mathrm{~g}}$-like orbitals by $\sim 0.8 \mathrm{eV}$, leading to high ${ }^{3} \mathrm{MLCT}$ energies

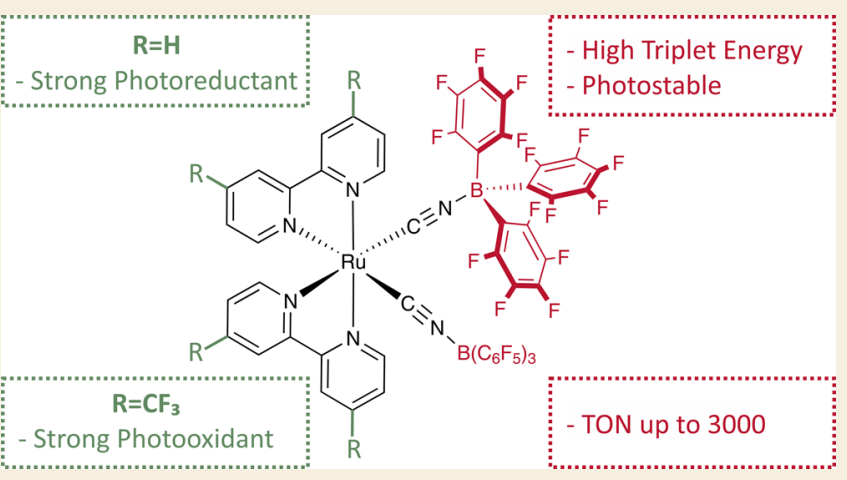
(up to $2.50 \mathrm{eV}$ ) that are more typical for cyclometalated iridium(III) complexes. Through variation of their $\alpha$-diimine ligands, nonradiative excited-state relaxation pathways involving higher-lying metal-centered states can be controlled, and their luminescence quantum yields and MLCT lifetimes can be optimized. These combined properties make the respective isocyanoborato complexes amenable to photochemical reactions for which common ruthenium(II)-based sensitizers are unsuited, due to a lack of sufficient triplet energy or excited-state redox power. Specifically, this includes photoisomerization reactions, sensitization of nickel-catalyzed cross-couplings, pinacol couplings, and oxidative decarboxylative $\mathrm{C}-\mathrm{C}$ couplings. Our work is relevant in the greater context of tailoring photoactive coordination compounds to current challenges in synthetic photochemistry and solar energy conversion.

KEYWORDS: coordination chemistry, photocatalysis, photoluminescence, energy transfer, ligand design, solar energy conversion

W hile photoredox catalysis can rely on electron transfer from singlet or triplet excited states, the emerging field of energy transfer catalysis crucially depends on triplet excited states. ${ }^{1}$ Due to high intersystem crossing efficiencies, many metal-based photosensitizers provide access to states that can undergo triplet-triplet energy transfer (TTET) with suitable substrates. Recently, this type of photochemical activation gained increasing attention in organic synthetic photochemistry, because triplet excited substrates can exhibit reactivities that are unattainable from their electronic ground states and their singlet-excited states. ${ }^{2}$ Specific examples include the photocatalytic generation of singlet oxygen for pericyclic reactions, ${ }^{3}$ cycloadditions, ${ }^{4-10} \mathrm{E} / \mathrm{Z}$ isomerizations, ${ }^{11}$ syntheses of cyclopropanes, ${ }^{12}$ sensitization of nickel catalysts, ${ }^{13}$ the carbocyclization/gem-diborylation, ${ }^{14}$ and the disulfide-ene reaction. ${ }^{15}$ Direct excitation of the substrates to their triplet excited states is spin-forbidden, and intersystem crossing from singlet to triplet excited states is frequently very inefficient in organic compounds; hence, metal-based triplet sensitizers are vital for many of these reactions. ${ }^{16}$ Iridium(III) photosensitizers are often chosen due to their high triplet energies $\left(E_{\mathrm{T}}\right.$, up to $\left.2.87 \mathrm{eV}\right)$, long excited-state lifetimes, and their thermal and photostability. ${ }^{17-19}$ In recent years, photo- sensitizers based on earth-abundant metals have gained increasing attention, ${ }^{20-23}$ but many of them still require further development to become as widely applicable as their precious metal-based congeners, and until now, ruthenium(II) and iridium(III) sensitizers have remained the workhorses of synthetic photochemistry and applications in solar energy conversion. ${ }^{24-26}$ Against this background, the development of ruthenium(II)- and iridium(III)-based photosensitizers continues to be important. ${ }^{27-46}$

Compared to iridium(III) complexes, ruthenium(II)-based photosensitizers typically have much lower triplet energies $(2.0-2.2 \mathrm{eV} \text {, Figure } 1 \mathrm{a})^{47}$ and therefore cannot catalyze many of the above-mentioned reactions. For ruthenium(II) phosphine complexes, higher triplet energies (2.2-2.4 eV) have been reported, though these compounds were not used as

Received: March 24, 2021

Published: May 13, 2021 
previous work a)

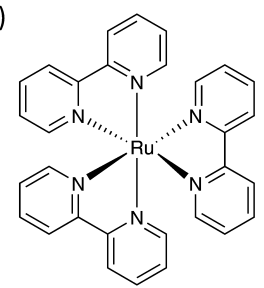

$\mathrm{E}_{\mathrm{T}}=2.03 \mathrm{eV}$

poor photostability b)

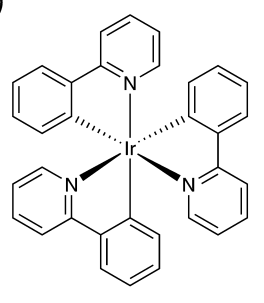

$\mathrm{E}_{\mathrm{T}}=2.50 \mathrm{eV}$

more photostable potent photoreductant

this work
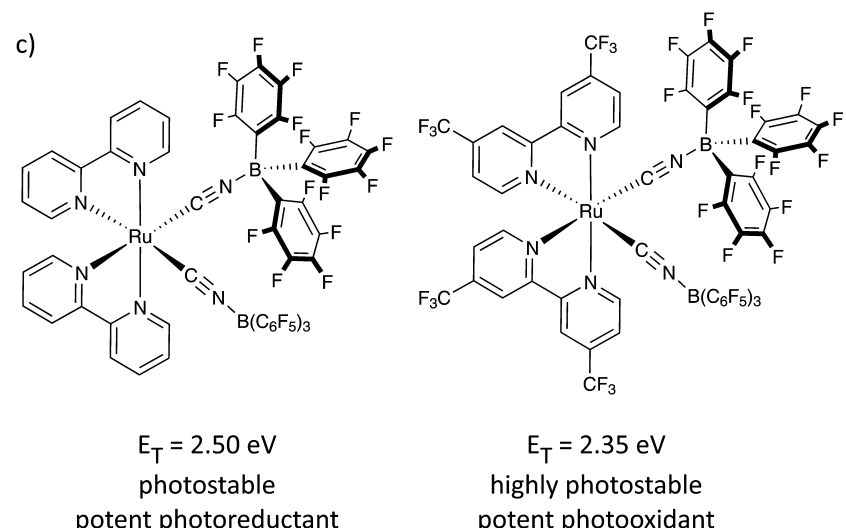

Figure 1. Top: chemical structures of $\left[\mathrm{Ru}(\mathrm{bpy})_{3}\right]^{2+}$ (a) and $\mathrm{fac}$ $\left[\operatorname{Ir}(\mathrm{ppy})_{3}\right]$ (b). Bottom: chemical structures of $\left[\mathrm{Ru}(\mathrm{bpy})_{2}(\mathrm{BCF})_{2}\right]$ and $\left[\mathrm{Ru}\left(\mathrm{CF}_{3} \mathrm{bpy}\right)_{2}(\mathrm{BCF})_{2}\right](\mathrm{c})\left(\mathrm{BCF}=\mathrm{CNB}\left(\mathrm{C}_{6} \mathrm{~F}_{5}\right)_{3}\right)$.

photocatalysts. $^{48-50}$ Furthermore, the ruthenium(II) methyl isocyanide complexes $\left[\mathrm{Ru}(\mathrm{bpy})_{2}(\mathrm{CNMe})_{2}\right]^{2+}\left(\right.$ bpy $=2,2^{\prime}$ bipyridine) and $\left[\mathrm{Ru}(\mathrm{bpy})(\mathrm{CNMe})_{4}\right]^{2+}$ exhibit unusually high triplet energies of 2.6 and $2.8 \mathrm{eV}$, respectively, but [Ru$\left.(\text { bpy })_{2}(\mathrm{CNMe})_{2}\right]^{2+}$ is nonemissive at room temperature, and $\left[\mathrm{Ru}(\mathrm{bpy})(\mathrm{CNMe})_{4}\right]^{2+}$ is prone to photodegradation. ${ }^{51}$

Here, we present a concept to elevate the triplet energies $\left(E_{\mathrm{T}}\right)$ of ruthenium(II) complexes up to the level of the prototypical cyclometalated iridium(III) complex fac-[Ir$\left.(\mathrm{ppy})_{3}\right]$ (Figure 1b, ppy = 2-phenylpyridine). Specifically, we demonstrate that borylation of well-known and easily accessible ruthenium(II) cyanide complexes yields not only potent triplet photosensitizers with broad application potential in photoredox and energy transfer catalysis but also remarkably photorobust new types of luminophores. Inspired by recent work on isocyanoborato complexes of iron and ruthenium with an electrochemical and spectroscopic focus, ${ }^{52-54}$ we synthesized and explored the $\left[\mathrm{Ru}(\mathrm{bpy})_{2}(\mathrm{BCF})_{2}\right](\mathrm{BCF}=\mathrm{CNB}-$ $\left.\left(\mathrm{C}_{6} \mathrm{~F}_{5}\right)_{3}\right)$ and the $\left[\mathrm{Ru}\left(\mathrm{CF}_{3} \mathrm{bpy}\right)_{2}(\mathrm{BCF})_{2}\right]$ complex (Figure 1c). While $\left[\mathrm{Ru}(\mathrm{bpy})_{2}(\mathrm{BCF})_{2}\right]$ has an unusually high triplet energy, $\left[\mathrm{Ru}\left(\mathrm{CF}_{3} \mathrm{bpy}\right)_{2}(\mathrm{BCF})_{2}\right]$ is a very potent photooxidant, making these compounds amenable to energy-transfer- and photoredox-catalyzed reactions, which are usually performed with iridium(III) photosensitizers. In direct comparative studies, both new sensitizers show far greater inherent photostability than $\left[\mathrm{Ru}(\mathrm{bpy})_{3}\right]^{2+}$ and $f a c-\left[\operatorname{Ir}(\text { ppy })_{3}\right]$ (Figure $\left.1 \mathrm{a}, \mathrm{b}\right)$, which is important for photocatalysis, because complete substrate turnover usually requires long $(>1 \mathrm{~h})$ irradiation times.
Important prior work on isocyanoborato complexes focused on 5d metals including $\operatorname{Ir}(\mathrm{III}),{ }^{55} \operatorname{Re}(\mathrm{I}),{ }^{56-59}$ and $\mathrm{Os}(\mathrm{II})^{61}$ as well as on $\mathrm{Ni}(\mathrm{II}),{ }^{62} \mathrm{Pd}(\mathrm{II}),{ }^{63} \mathrm{Pt}(\mathrm{II}),{ }^{64} \mathrm{Cu}(\mathrm{I}),{ }^{60,65}$ and $\mathrm{Ag}(\mathrm{I}) .{ }^{60}$ Very recently, $\mathrm{Ru}(\mathrm{II})$ and $\mathrm{Fe}(\mathrm{II})$ isocyanoborato complexes were studied in the context of electrochemistry and spectroscopy, but their photoreactivity and photochemistry have not yet been reported. ${ }^{52-54}$ Attachment of $\mathrm{B}\left(\mathrm{C}_{6} \mathrm{~F}_{5}\right)$ moieties to the cyanide ligands of heteroleptic complexes with $\alpha$-diimine chelates usually results in the stabilization of the metalcentered $\mathrm{d}$ orbitals, whereas the diimine $\pi^{*}$ orbitals are less affected. $^{53}$ This leads to a blue-shift of the metal-to-ligand charge-transfer (MLCT) absorption and emission features and a concomitant increase in ${ }^{3}$ MLCT energy. ${ }^{55-59}$ The photostability of our new $\mathrm{Ru}$ (II) compounds and their broad applicability to photocatalysis is largely attributable to this effect.

The present study of isocyanoborato complexes of ruthenium(II) complements recent work on isocyanide complexes with the $\mathrm{d}^{6}$-metals $\mathrm{W}(0),{ }^{66-69} \mathrm{Mo}(0),{ }^{70-72}$ and $\operatorname{Cr}(0)^{73}$ and provides additional fundamental insight into how strong-field $\pi$-acceptor ligands can be used to tailor photophysical and photochemical properties.

\section{RESULTS AND DISCUSSION}

Synthesis, Characterization, IR Spectroscopy, and Crystal Structures

$\left[\mathrm{Ru}(\mathrm{bpy})_{2}(\mathrm{BCF})_{2}\right]$ and $\left[\mathrm{Ru}\left(\mathrm{CF}_{3} \mathrm{bpy}\right)_{2}(\mathrm{BCF})_{2}\right]$ were synthesized by reacting $\left[\mathrm{Ru}(\mathrm{bpy})_{2}(\mathrm{CN})_{2}\right]$ and $\left[\mathrm{Ru}\left(\mathrm{CF}_{3} \text { bpy }\right)_{2}(\mathrm{CN})_{2}\right]$ with 2.2 equiv of $\mathrm{B}\left(\mathrm{C}_{6} \mathrm{~F}_{5}\right)_{3}$ under inert conditions to form the Lewis adducts. Both complexes were characterized by IR as well as ${ }^{13} \mathrm{C},{ }^{1} \mathrm{H},{ }^{19} \mathrm{~F}$, and ${ }^{11} \mathrm{~B}$ NMR spectroscopy and also elemental analysis, mass spectrometry, and single-crystal X-ray diffraction. The infrared spectrum of the $\left[\mathrm{Ru}(\mathrm{bpy})_{2}(\mathrm{CN})_{2}\right]$ precursor exhibits two $\mathrm{C} \equiv \mathrm{N}$ stretching bands at 2064 and $2045 \mathrm{~cm}^{-1}$, which shift to 2159 and $2063 \mathrm{~cm}^{-1}$ in $\left[\mathrm{Ru}(\text { bpy })_{2}(\mathrm{BCF})_{2}\right]$ (Figure S15). The Lewis-acidic $\mathrm{B}\left(\mathrm{C}_{6} \mathrm{~F}_{5}\right)_{3}$ moiety lowers the energy of the relevant $\mathrm{C} \equiv \mathrm{N} \pi$-bonding orbitals and commonly increases the $\mathrm{C} \equiv \mathrm{N}$ stretch frequencies of isocyanoborato complexes compared to their cyanide congeners. ${ }^{52,53,56,61}$ Similarly, in $\left[\mathrm{Ru}\left(\mathrm{CF}_{3} \text { bpy }\right)_{2}(\mathrm{BCF})_{2}\right]$, the two respective IR bands appear at 2173 and $2195 \mathrm{~cm}^{-1}$, while in $\left[\mathrm{Ru}\left(\mathrm{CF}_{3} \mathrm{bpy}\right)_{2}(\mathrm{CN})_{2}\right]$, they are at 2085 and $2094 \mathrm{~cm}^{-1}$ (Figure S16).

Single crystals suitable for X-ray diffraction were obtained for both new complexes by slow evaporation from a mixture of $\mathrm{CHCl}_{3}$ and $\mathrm{CH}_{2} \mathrm{Cl}_{2}\left(\left[\mathrm{Ru}(\mathrm{bpy})_{2}(\mathrm{BCF})_{2}\right]\right)$ or slow evaporation of $\mathrm{CD}_{2} \mathrm{Cl}_{2}$ from a solution of $\left[\mathrm{Ru}\left(\mathrm{CF}_{3} \mathrm{bpy}\right)_{2}(\mathrm{BCF})_{2}\right]$, resulting in the structures shown in Figure 2. Though both compounds were obtained as racemic mixtures (as confirmed by circular dichroism spectroscopy, Figure S26), only one enantiomer crystallized in each case, namely the $\Lambda$-isomer of $[\mathrm{Ru}$ $\left.(\text { bpy })_{2}(\mathrm{BCF})_{2}\right]$ and the $\Delta$-isomer of $\left[\mathrm{Ru}\left(\mathrm{CF}_{3} \mathrm{bpy}\right)_{2}(\mathrm{BCF})_{2}\right]$ (see SI page S19 for details). In both complexes, the average $\mathrm{C}-\mathrm{N}-\mathrm{B}$ angles are slightly bent $\left(175.26(18)^{\circ}\right.$ in $[\mathrm{Ru}-$ $\left.(\text { bpy })_{2}(\mathrm{BCF})_{2}\right]$ and $168.60(3)^{\circ}$ in $\left.\left[\mathrm{Ru}\left(\mathrm{CF}_{3} \mathrm{bpy}\right)_{2}(\mathrm{BCF})_{2}\right]\right)$, presumably due to a combination of steric effects and $\pi$ backbonding from the $\mathrm{Ru}(\mathrm{II})$ center to the isocyanoborato ligand. ${ }^{52,55,56}$ An X-ray crystal structure of the [Ru$(\text { bpy })_{2}(\mathrm{CN})_{2}$ ] parent complex is not available, but compared to the closely related $\left[\mathrm{Ru}(\mathrm{dtbbpy})_{2}(\mathrm{CN})_{2}\right]$ complex $^{74}$ (dtbbpy $=4,4^{\prime}$-di-tert-butyl-2,2'-bipyridine), the $\mathrm{C} \equiv \mathrm{N}$ bond distances are shorter by $0.021(4) \AA$ in $\left[\mathrm{Ru}\left(\mathrm{CF}_{3} \text { bpy }\right)_{2}(\mathrm{BCF})_{2}\right]$ and by 

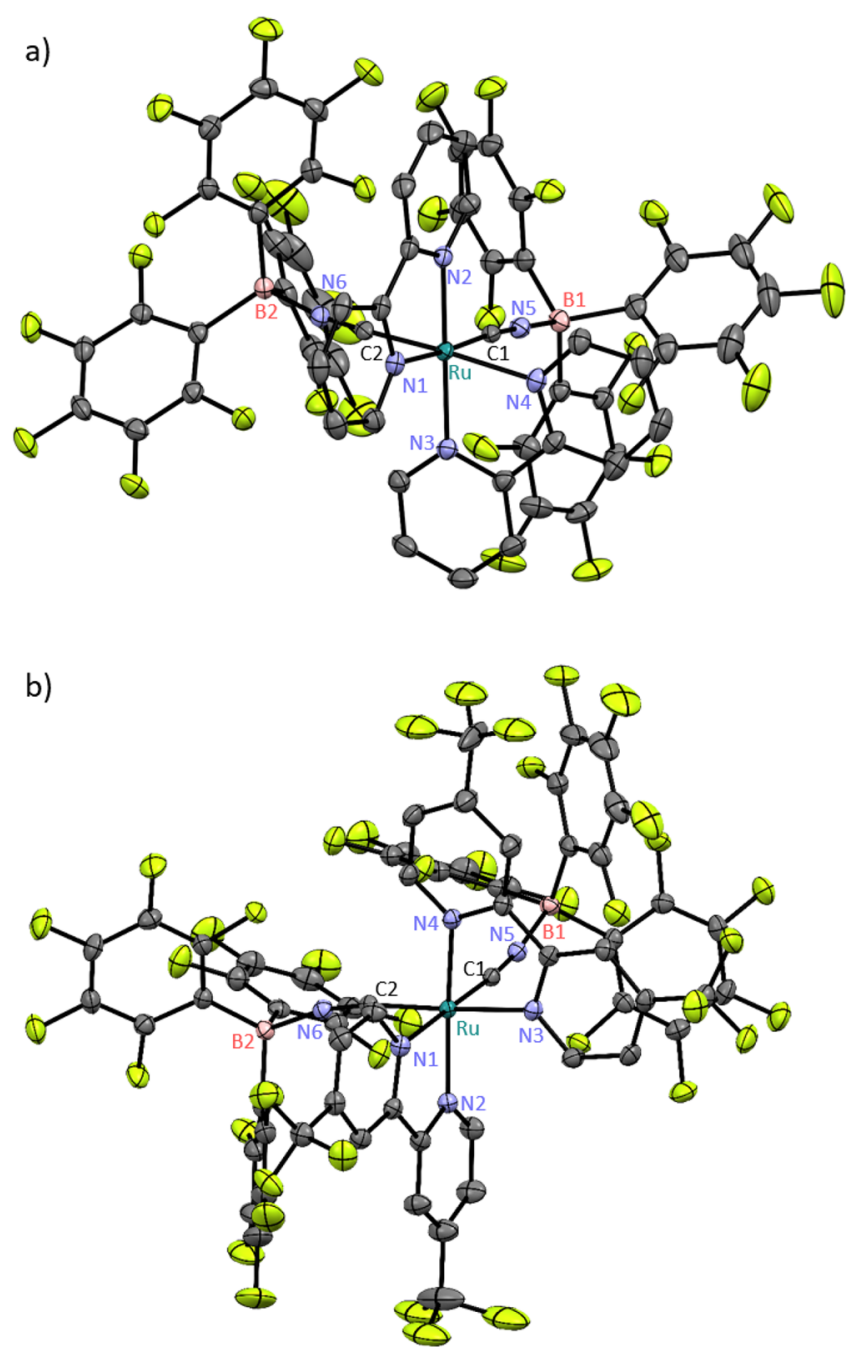

Figure 2. X-ray crystal structures of $\Lambda$ - $\left[\mathrm{Ru}(\mathrm{bpy})_{2}(\mathrm{BCF})_{2}\right](\mathrm{a})$ and $\Delta$ $\left[\mathrm{Ru}\left(\mathrm{CF}_{3} \mathrm{bpy}\right)_{2}(\mathrm{BCF})_{2}\right]$ (b) shown as $50 \%$ thermal ellipsoids. Hydrogen atoms are omitted for clarity.

$0.013(2) \AA$ in $\left[\mathrm{Ru}(\mathrm{bpy})_{2}(\mathrm{BCF})_{2}\right]$, in line with their increased $\mathrm{C} \equiv \mathrm{N}$ stretching frequencies. Furthermore, compared to $\left[\mathrm{Ru}(\mathrm{dtbbpy})_{2}(\mathrm{CN})_{2}\right]$, the $\mathrm{Ru}-\mathrm{C}$ bonds are $0.050(17) \AA$ shorter in $\left[\mathrm{Ru}(\mathrm{bpy})_{2}(\mathrm{BCF})_{2}\right.$ and $0.032(3) \AA$ shorter in $\left[\mathrm{Ru}\left(\mathrm{CF}_{3} \mathrm{bpy}\right)_{2}(\mathrm{BCF})_{2}\right]$ as a result of enhanced $\pi$-backbonding between the metal and the BCF ligand. Prior studies demonstrated that the $\sigma$-bonding interaction between the metal and the carbon atom is weakened in isocyanoborato complexes compared to the nonborylated cyanide parent complexes, ${ }^{52,53}$ because the Lewis acidity of $\mathrm{B}\left(\mathrm{C}_{6} \mathrm{~F}_{5}\right)_{3}$ decreases the electron density at the carbon atom. However, in our complexes, this effect of weakened $\sigma$-bonding is apparently overcompensated by other effects.

In the cyclic voltammograms of $\left[\mathrm{Ru}(\text { bpy })_{2}(\mathrm{BCF})_{2}\right]$ (Figure $3 \mathrm{a}$, middle) and $\left[\mathrm{Ru}\left(\mathrm{CF}_{3} \mathrm{bpy}\right)_{2}(\mathrm{BCF})_{2}\right]$ (Figure 3a, bottom), two waves attributable to consecutive one-electron reduction of the two individual bpy ligands and one wave due to oxidation of $\mathrm{Ru}$ (II) to $\mathrm{Ru}$ (III) are observable.

In $\left[\mathrm{Ru}(\mathrm{bpy})_{2}(\mathrm{BCF})_{2}\right]$, the metal-based oxidation occurs at $1.63 \mathrm{~V}$ vs SCE, i.e., at $0.77 \mathrm{~V}$ more positive potential than in the $\left[\mathrm{Ru}(\mathrm{bpy})_{2}(\mathrm{CN})_{2}\right]$ parent complex (see Figure S27 for the cyclic voltammogram), indicating the metal-based $t_{2 \mathrm{~g}}$-like orbitals are strongly stabilized upon borylation (Figure a)

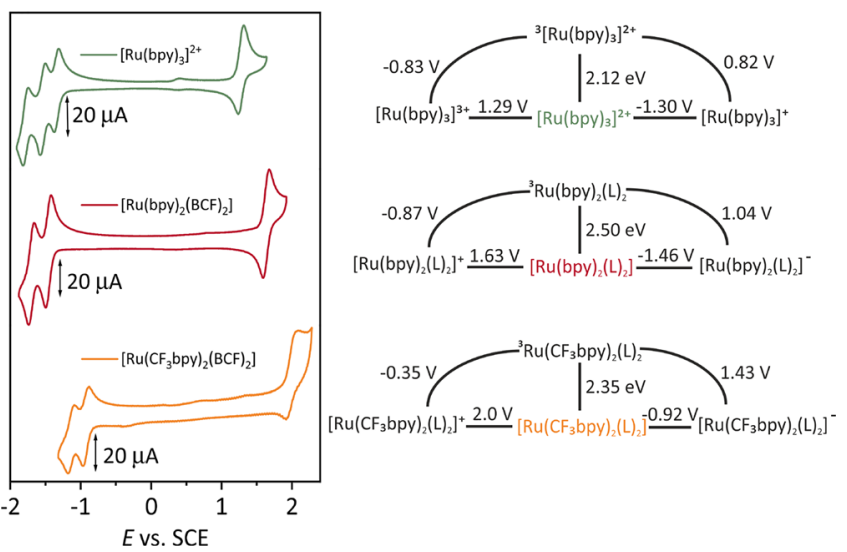

Figure 3. (a) Cyclic voltammograms of $0.6 \mathrm{mM}\left[\mathrm{Ru}(\mathrm{bpy})_{3}\right]\left[\mathrm{PF}_{6}\right]_{2}$ (top), $1 \mathrm{mM}\left[\mathrm{Ru}(\mathrm{bpy})_{2}(\mathrm{~L})\right]_{2}$ (middle), and $0.6 \mathrm{mM}\left[\mathrm{Ru}\left(\mathrm{CF}_{3} \mathrm{bpy}\right)_{2}\right.$ $(\mathrm{L})_{2}$ ] (bottom); $\mathrm{L}=\mathrm{BCF}$, in dry deaerated $\mathrm{CH}_{3} \mathrm{CN}$ at room temperature with $0.1 \mathrm{M}\left[\mathrm{NBu}_{4}\right]\left[\mathrm{PF}_{6}\right]$ as a supporting electrolyte. The scan rate was $0.1 \mathrm{~V} / \mathrm{s}$ in all three cases. (b) Latimer diagrams of the three complexes based on the voltammograms shown in a, including the energies of their photoactive ${ }^{3} \mathrm{MLCT}$ excited states derived from the spectroscopic studies discussed below. Redox potentials for complexes in their electronic ground and ${ }^{3} \mathrm{MLCT}$ excited states are reported in V vs SCE.

4a). ${ }^{56,61}$ Analogously, the respective metal-centered orbitals are stabilized by $0.86 \mathrm{eV}$ in $\left[\mathrm{Ru}\left(\mathrm{CF}_{3} \text { bpy }\right)_{2}(\mathrm{BCF})_{2}\right]$ compared to $\left[\mathrm{Ru}\left(\mathrm{CF}_{3} \mathrm{bpy}\right)_{2}(\mathrm{CN})_{2}\right]$ (Figure $4 \mathrm{~b}$ ).

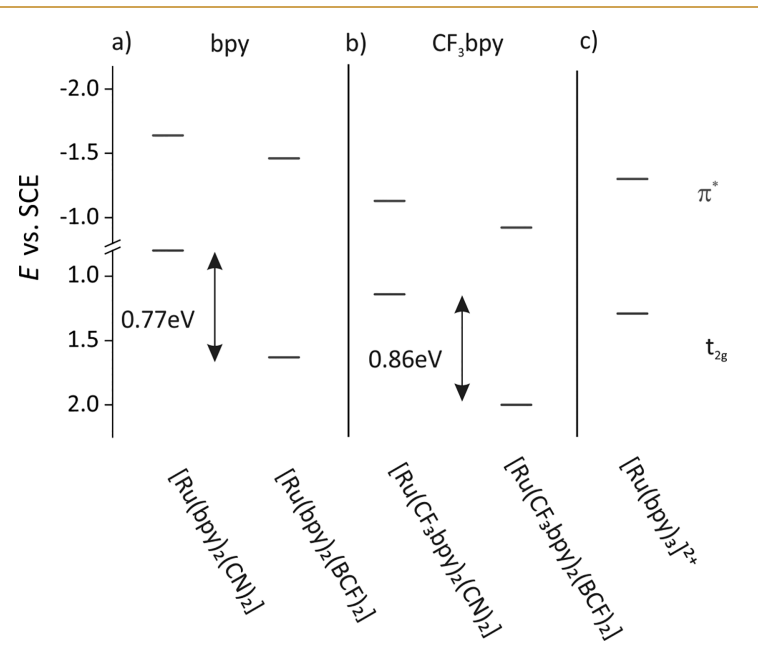

Figure 4. Energy-level diagrams illustrating the effect of borylation on the metal-centered $\mathrm{t}_{2 \mathrm{~g}}$-like and ligand-based $\pi^{*}$ orbitals, derived from the electrochemical measurements in Figure 3.

Borylation furthermore entails an energetic stabilization of the bpy-ligand-based $\pi^{*}$ orbitals relative to the corresponding cyanide complexes, but this effect is smaller than the stabilization of the $t_{2 g}$-like orbitals: The reduction potential of $\left[\mathrm{Ru}(\mathrm{bpy})_{2}(\mathrm{BCF})_{2}\right]$ is $-1.46 \mathrm{~V}$ vs SCE, compared to -1.68 $\mathrm{V}$ vs SCE for $\left[\mathrm{Ru}(\text { bpy })_{2}(\mathrm{CN})_{2}\right]$, while the reduction potential of $\left[\mathrm{Ru}\left(\mathrm{CF}_{3} \mathrm{bpy}\right)_{2}(\mathrm{BCF})_{2}\right]$ is $0.21 \mathrm{~V}$ less negative than that of $\left[\mathrm{Ru}\left(\mathrm{CF}_{3} \mathrm{bpy}\right)_{2}(\mathrm{CN})_{2}\right]$. Thus, based on the electrochemical data, one can anticipate that the ${ }^{3} \mathrm{MLCT}$ energies of the two complexes from Figure 1c will be up to $0.6 \mathrm{eV}$ higher than those of the respective cyanide parent compounds, and this 
expectation is indeed fulfilled as discussed in the following sections.

The one-electron reduced $\left[\mathrm{Ru}(\mathrm{bpy})_{2}(\mathrm{BCF})_{2}\right]$ complex, $\left[\mathrm{Ru}(\mathrm{bpy})_{2}(\mathrm{BCF})_{2}\right]^{-}$, should be a relatively potent reductant, roughly $0.16 \mathrm{~V}$ more reducing than $\left[\mathrm{Ru}(\mathrm{bpy})_{3}\right]^{+}$(Figure $3 \mathrm{~b}$ ). As demonstrated further below, $\left[\mathrm{Ru}(\mathrm{bpy})_{2}(\mathrm{BCF})_{2}\right]^{-}$is photochemically easily accessible by excitation and subsequent reduction by a suitable sacrificial electron donor, and this can be exploited to drive photochemical reactions that are unattainable with $\left[\mathrm{Ru}(\mathrm{bpy})_{3}\right]^{+}$.

While the $\left[\mathrm{Ru}(\mathrm{bpy})_{2}(\mathrm{BCF})_{2}\right]$ complex is suitable for reductive photoredox catalysis, the $\left[\mathrm{Ru}\left(\mathrm{CF}_{3} \mathrm{bpy}\right)_{2}(\mathrm{BCF})_{2}\right]$ compound with its electron-withdrawing $\mathrm{CF}_{3}$ substituents at the bipyridine ligands is an attractive candidate for oxidative photocatalysis, due to its high excited-state reduction potential of $1.43 \mathrm{~V}$ vs SCE. This is $0.61 \mathrm{~V}$ more oxidizing than ${ }^{3}$ MLCTexcited $\left[\mathrm{Ru}(\mathrm{bpy})_{3}\right]^{2+}$ (Figure $3 \mathrm{~b}$ ) and approaches the typical values reached for cyclometalated (heteroleptic) iridium(III) complexes $^{17,33}$ and certain acridinium dyes. ${ }^{75,76}$ The main point, however, is the strongly elevated ${ }^{3}$ MLCT energy of the two new complexes, as discussed in the following.

\section{UV-Vis Absorption and Luminescence Properties}

The MLCT absorption and emission bands of [Ru$\left.(\text { bpy })_{2}(\mathrm{BCF})_{2}\right]$ and $\left[\mathrm{Ru}\left(\mathrm{CF}_{3} \text { bpy }\right)_{2}(\mathrm{BCF})_{2}\right]$ are markedly blue-shifted compared to $\left[\mathrm{Ru}(\mathrm{bpy})_{3}\right]^{2+}$ and the respective ruthenium(II) cyanide parent compounds (Figure 5 and Table 1).

Specifically, the emission band maxima of [ $\mathrm{Ru}-$ $\left.(\text { bpy })_{2}(\mathrm{BCF})_{2}\right]$ and $\left[\mathrm{Ru}\left(\mathrm{CF}_{3} \mathrm{bpy}\right)_{2}(\mathrm{BCF})_{2}\right]$ are at $\sim 4000$ $\mathrm{cm}^{-1}$ higher energy than in $\left[\mathrm{Ru}(\mathrm{bpy})_{2}(\mathrm{CN})_{2}\right]$ and $[\mathrm{Ru}-$ $\left.\left(\mathrm{CF}_{3} \text { bpy }\right)_{2}(\mathrm{CN})_{2}\right]$, in reasonable agreement with the abovementioned shifts of metal-based oxidation and ligand-centered reduction potentials upon introduction of the $B\left(\mathrm{C}_{6} \mathrm{~F}_{5}\right)_{3}$ moieties (ca. $0.6 \mathrm{eV}$ or ca. $4800 \mathrm{~cm}^{-1}$ ).

Evidently, the blue-shifted emission of [Ru$\left.\left(\mathrm{CF}_{3} \mathrm{bpy}\right)_{2}(\mathrm{BCF})_{2}\right]$ and $\left[\mathrm{Ru}(\mathrm{bpy})_{2}(\mathrm{BCF})_{2}\right]$ is due to considerably elevated ${ }^{3} \mathrm{MLCT}$ energies, and this is confirmed by $77 \mathrm{~K}$ luminescence measurements, which reveal a triplet energy of $2.50 \mathrm{eV}$ for $\left[\mathrm{Ru}(\mathrm{bpy})_{2}(\mathrm{BCF})_{2}\right]$ (right inset in Figure 5a) and $2.35 \mathrm{eV}$ for $\left[\mathrm{Ru}\left(\mathrm{CF}_{3} \mathrm{bpy}\right)_{2}(\mathrm{BCF})_{2}\right]$ (right inset in Figure $5 \mathrm{~b}$ ). DFT calculations confirm the unusually high value for $\left[\mathrm{Ru}(\mathrm{bpy})_{2}(\mathrm{BCF})_{2}\right]$; see below. The vibrational fine structures present in the low-temperature emission spectra of $[\mathrm{Ru}-$ $\left.(\mathrm{bpy})_{2}(\mathrm{BCF})_{2}\right]$ and $\left[\mathrm{Ru}\left(\mathrm{CF}_{3} \mathrm{bpy}\right)_{2}(\mathrm{BCF})_{2}\right]$ (including progressions in a $1250 \mathrm{~cm}^{-1}$ mode in both complexes) signal that their emissive excited states under these conditions likely have significant intraligand character. ${ }^{77}$

The natural (unquenched) ${ }^{3} \mathrm{MLCT}$ excited-state lifetime $\left(\tau_{0}\right)$ of $\left[\mathrm{Ru}\left(\mathrm{CF}_{3} \text { bpy }\right)_{2}(\mathrm{BCF})_{2}\right]$ in Ar-saturated $\mathrm{CH}_{3} \mathrm{CN}$ at 20 ${ }^{\circ} \mathrm{C}$ is 1043 ns (left inset of Figure 5b), which is 10 times longer compared to $\left[\mathrm{Ru}\left(\mathrm{CF}_{3} \mathrm{bpy}\right)_{2}(\mathrm{CN})_{2}\right]$. This drastic lifetime elongation is attributed to the significantly increased energy gap between the emissive ${ }^{3} \mathrm{MLCT}$ and the electronic ground state upon borylation, making nonradiative relaxation less competitive. $^{78}$ This is underlined by the higher photoluminescence quantum yield of $\left[\mathrm{Ru}\left(\mathrm{CF}_{3} \mathrm{bpy}\right)_{2}(\mathrm{BCF})_{2}\right]$ $(12.8 \%)$ compared to $\left[\mathrm{Ru}\left(\mathrm{CF}_{3} \mathrm{bpy}\right)_{2}(\mathrm{CN})_{2}\right](\leq 3.5 \%)$. The excited-state lifetime elongation and the increased quantum yield upon borylation of $\left[\mathrm{Ru}\left(\mathrm{CF}_{3} \text { bpy }\right)_{2}(\mathrm{CN})_{2}\right]$ reflect a decrease of the nonradiative decay rate constant $\left(k_{\mathrm{nr}}\right)$ by a factor of 11 (Table 1). Specifically, $k_{\mathrm{nr}}$ decreases from $9.46 \cdot 10^{6}$ $\mathrm{s}^{-1}$ in $\left[\mathrm{Ru}\left(\mathrm{CF}_{3} \mathrm{bpy}\right)_{2}(\mathrm{CN})_{2}\right]$ to $8.39 \cdot 10^{5} \mathrm{~s}^{-1}$ in $[\mathrm{Ru}-$
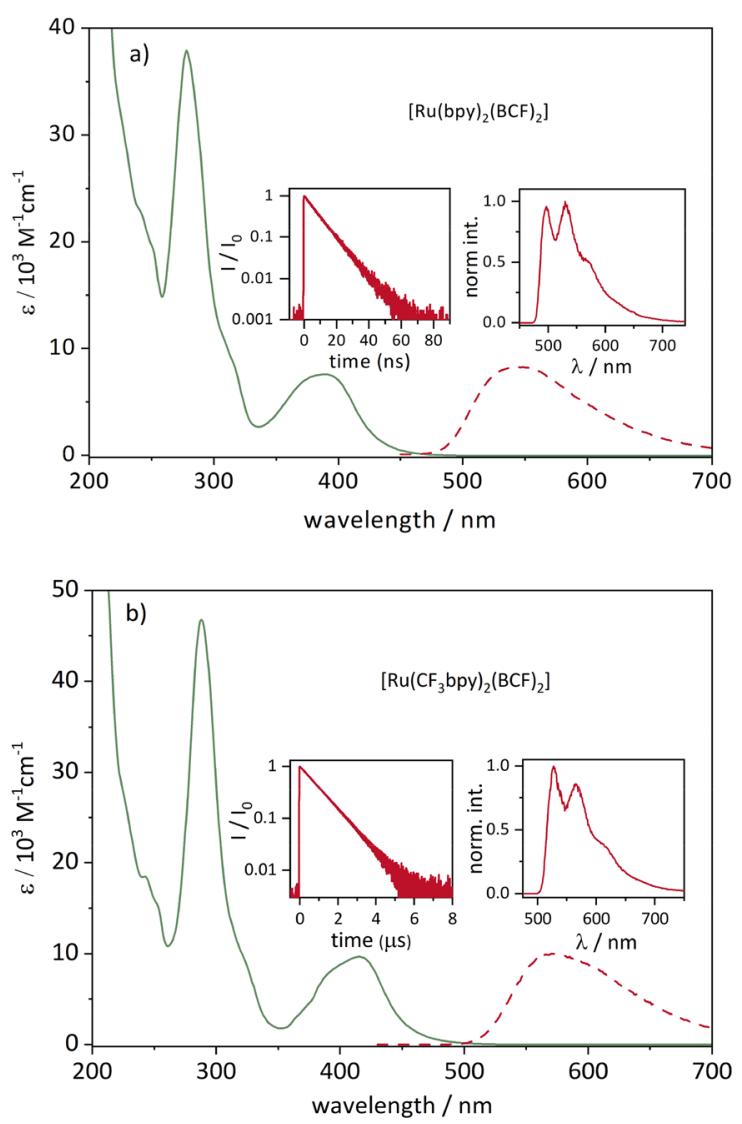

Figure 5. Main plots: UV-vis absorption (solid green lines) and normalized luminescence spectra (dashed red lines) of [Ru$\left.(\text { bpy })_{2}(\mathrm{BCF})_{2}\right]$ (a) and $\left[\mathrm{Ru}\left(\mathrm{CF}_{3} \mathrm{bpy}\right)_{2}(\mathrm{BCF})_{2}\right]$ (b) recorded in dry, deaerated $\mathrm{CH}_{3} \mathrm{CN}$ at $293 \mathrm{~K}$. Left insets: Luminescence decay of $10^{-5}$ $\mathrm{M}\left[\mathrm{Ru}(\mathrm{bpy})_{2}(\mathrm{BCF})_{2}\right]$ (a) and $10^{-5} \mathrm{M}\left[\mathrm{Ru}\left(\mathrm{CF}_{3} \mathrm{bpy}\right)_{2}(\mathrm{BCF})_{2}\right]$ (b) in dry, deaerated $\mathrm{CH}_{3} \mathrm{CN}$ at $293 \mathrm{~K}$ following excitation at $375 \mathrm{~nm}$ with laser pulses of $\sim 60 \mathrm{ps}$ duration. Right insets: Luminescence spectrum of $\left[\mathrm{Ru}(\mathrm{bpy})_{2}(\mathrm{BCF})_{2}\right](\mathrm{a})$ and $\left[\mathrm{Ru}\left(\mathrm{CF}_{3} \mathrm{bpy}\right)_{2}(\mathrm{BCF})_{2}\right]$ (b) recorded at $77 \mathrm{~K}$ in 2-methyl-THF. For the steady-state luminescence measurements, excitation occurred at $390 \mathrm{~nm}\left(\left[\mathrm{Ru}(\mathrm{bpy})_{2}(\mathrm{BCF})_{2}\right]\right)$ and at $420 \mathrm{~nm}\left(\left[\mathrm{Ru}\left(\mathrm{CF}_{3} \text { bpy }\right)_{2}(\mathrm{BCF})_{2}\right]\right)$.

$\left.\left(\mathrm{CF}_{3} \mathrm{bpy}\right)_{2}(\mathrm{BCF})_{2}\right]$. Similar observations have been previously made for isocyanoborato complexes of 5d metals. ${ }^{56,57,61}$

Strikingly, under identical conditions, the natural ${ }^{3} \mathrm{MLCT}$ lifetime of $\left[\mathrm{Ru}(\mathrm{bpy})_{2}(\mathrm{BCF})_{2}\right]$ is only $8.6 \mathrm{~ns}$ (left inset of Figure 5a), 30 times shorter than in the parent cyanide complex, and the luminescence quantum yield is diminished from $\leq 3.2 \%$ in $\left[\mathrm{Ru}(\mathrm{bpy})_{2}(\mathrm{CN})_{2}\right]$ to $0.2 \%$ in $[\mathrm{Ru}-$ $\left.(\text { bpy })_{2}(\mathrm{BCF})_{2}\right]$. This unexpected behavior is attributed to the thermal population of a nearby metal-centered $\left({ }^{3} \mathrm{MC}\right)$ excited state, which opens an efficient nonradiative relaxation pathway due to its strong distortion relative to the ground state. Thus, $k_{\mathrm{nr}}$ increases from $3.87 \cdot 10^{6} \mathrm{~s}^{-1}$ for $[\mathrm{Ru}-$ $\left.(\text { bpy })_{2}(\mathrm{CN})_{2}\right]$ to $1.16 \cdot 10^{8} \mathrm{~s}^{-1}$ for $\left[\mathrm{Ru}(\mathrm{bpy})_{2}(\mathrm{BCF})_{2}\right]$.

According to the DFT calculations presented below, that ${ }^{3} \mathrm{MC}$ state is energetically only slightly higher in energy than the emissive ${ }^{3} \mathrm{MLCT}$ state. The small activation barrier for internal conversion from ${ }^{3} \mathrm{MLCT}$ to ${ }^{3} \mathrm{MC}$ seems to be the result of the larger increase in ${ }^{3} \mathrm{MLCT}$ energy compared to the increase in ${ }^{3} \mathrm{MC}$ energy upon borylation (dotted arrows in Figure 6), and thus, an excited-state relaxation pathway that typically plays an important role in $\mathrm{Fe}(\mathrm{II})$ and related $3 \mathrm{~d}^{6}$ complexes becomes operative for a $\mathrm{Ru}(\mathrm{II})$ compound. ${ }^{2,79-84}$ 
Table 1. Summary of Photophysical Properties of the Key Complexes ${ }^{a}$

\begin{tabular}{|c|c|c|c|c|c|c|c|}
\hline & $\lambda_{\text {max, abs, MLCT }}(\varepsilon) / \mathrm{nm}\left(\mathrm{M}^{-1} \mathrm{~cm}^{-1}\right)$ & $\lambda_{\text {max, em }} / \mathrm{nm}$ & $\tau_{0} / \mathrm{ns}$ & $E_{\mathrm{T}} / \mathrm{eV}$ & $k_{\mathrm{r}} / \mathrm{s}^{-1}$ & $k_{\mathrm{nr}} / \mathrm{s}^{-1}$ & $\Phi / \%$ \\
\hline$\left[\mathrm{Ru}(\mathrm{bpy})_{2}(\mathrm{CN})_{2}\right]$ & $496(5400)$ & 704 & 250 & - & $1.28 \cdot 10^{5 g}$ & $3.87 \cdot 10^{6 g}$ & $\leq 3.2^{f}$ \\
\hline$\left[\mathrm{Ru}(\mathrm{bpy})_{2}(\mathrm{BCF})_{2}\right]$ & $390(7500)$ & 543 & 8.6 & $2.50^{b}$ & $2.33 \cdot 10^{5}$ & $1.16 \cdot 10^{8}$ & 0.2 \\
\hline$\left[\mathrm{Ru}\left(\mathrm{CF}_{3} \mathrm{bpy}\right)_{2}(\mathrm{CN})_{2}\right]$ & $520(13000)$ & 742 & 102 & - & $3.43 \cdot 10^{5 h}$ & $9.46 \cdot 10^{6 h}$ & $\leq 3.5^{f}$ \\
\hline$\left[\mathrm{Ru}\left(\mathrm{CF}_{3} \mathrm{bpy}\right)_{2}(\mathrm{BCF})_{2}\right]$ & $416(10000)$ & 571 & 1040 & $2.35^{b}$ & $1.23 \cdot 10^{5}$ & $8.39 \cdot 10^{5}$ & 12.8 \\
\hline$\left[\mathrm{Ru}(\mathrm{bpy})_{3}\right]^{2+}$ & $452(13000)$ & 619 & 1019 & $2.12^{d}$ & - & - & $9.5^{e}$ \\
\hline $\mathrm{fac}-\left[\operatorname{Ir}(\mathrm{ppy})_{3}\right]$ & $373(12500)$ & 527 & 1750 & $2.50^{c}$ & - & - & $40^{d}$ \\
\hline
\end{tabular}

${ }^{a_{T}}$ The data were recorded in dry, deaerated $\mathrm{CH}_{3} \mathrm{CN}$ at $20{ }^{\circ} \mathrm{C}$. $\left(\lambda_{\max , \text { abs, MLCT }}\right.$ is the maximum of the MLCT absorption band; $\lambda_{\max , \text { em }}$ is the emission band maximum). ${ }^{b}$ Value obtained from $77 \mathrm{~K}$ measurements in 2-methyl-THF. ${ }^{c}$ From ref $86 .{ }^{d}$ From ref $87 .{ }^{e}$ From ref $88 .{ }^{f}$ Upper limit for instrumental reasons. See SI for details. ${ }^{g}$ Calculated on the basis of $\Phi=3.2 \%$ for $\left[\mathrm{Ru}(\mathrm{bpy})_{2}(\mathrm{CN})_{2}\right] .{ }^{h}$ Calculated on the basis of $\Phi=3.5 \%$ for $\left[\mathrm{Ru}\left(\mathrm{CF}_{3} \mathrm{bpy}\right)_{2}(\mathrm{CN})_{2}\right]$.

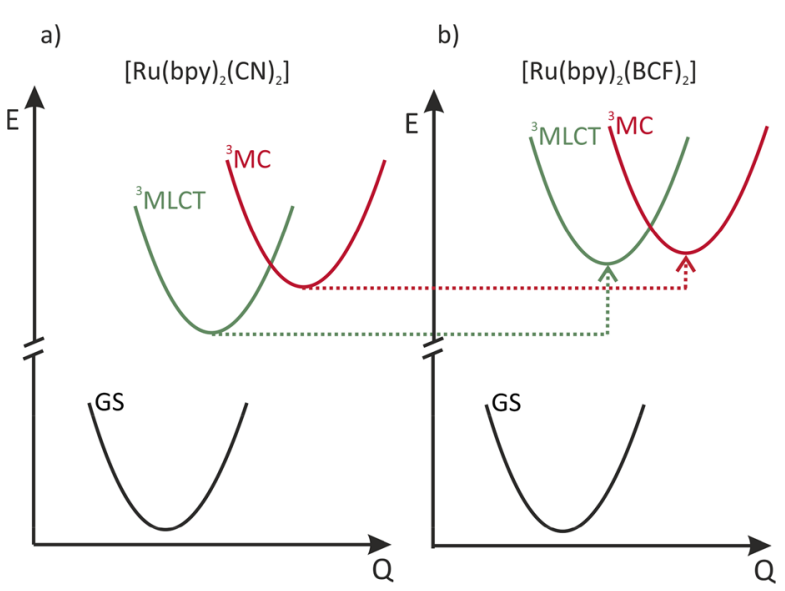

Figure 6. Schematic representation of the key potential energy wells of $\left[\mathrm{Ru}(\mathrm{bpy})_{2}(\mathrm{CN})_{2}\right](\mathrm{a})$ and $\left[\mathrm{Ru}(\mathrm{bpy})_{2}(\mathrm{BCF})_{2}\right](\mathrm{b}) . Q$ is a nuclear coordinate, and GS stands for ground state.

A somewhat related observation has been made for $[\mathrm{Ru}(\mathrm{tpy})$ $\left.(\mathrm{CN})_{3}\right]^{-}\left(\right.$tpy $=2,2^{\prime}: 6^{\prime}, 2^{\prime}$-terpyridine $)$ and $\left[\mathrm{Fe}(\mathrm{bpy})_{2}(\mathrm{CN})_{2}\right]$, where hydrogen-bond donating solvents interacted with the $\mathrm{CN}$ ligands and thereby decreased their electron density and lowered both the $\mathrm{e}_{\mathrm{g}}$ and $\mathrm{t}_{\mathrm{2g}}$ orbital energies. ${ }^{83,85}$ A qualitatively similar effect is expectable for borylation, which also decreases the electron density at the carbon atom of the cyanoborylated ligands.

As noted above, many prior investigations of cyanoborylated complexes have focused on $5 \mathrm{~d}$ metals, ${ }^{55-59,61,64}$ where the ligand field splitting is inherently larger than in $4 \mathrm{~d}$ metals and thermal population of the ${ }^{3} \mathrm{MC}$ from the ${ }^{3} \mathrm{MLCT}$ state is therefore less important. Thus, it is not too surprising that the effect illustrated by Figure 6 has been unnoticed until now. A plausible reason why this effect is not seen for $[\mathrm{Ru}-$ $\left.\left(\mathrm{CF}_{3} \mathrm{bpy}\right)_{2}(\mathrm{BCF})_{2}\right]$ is that the $\mathrm{CF}_{3}$ substituents stabilize the bpy-based $\pi^{*}$ LUMOs (Figure 4), thereby lowering the ${ }^{3} \mathrm{MLCT}$ energy and increasing the gap to the ${ }^{3} \mathrm{MC}$ state This interpretation is in line with the recently reported ${ }^{3} \mathrm{MLCT}$ lifetime elongation from $210 \mathrm{~ns}$ in $\left[\mathrm{Ru}(\mathrm{bpy})(\mathrm{BCF})_{4}\right]^{2-}$ to $3400 \mathrm{~ns}$ in $\left[\mathrm{Ru}\left(\mathrm{CF}_{3} \text { bpy }\right)(\mathrm{BCF})_{4}\right]^{2-54}$

\section{Transient Absorption Spectroscopy and DFT Calculations}

The spectral features in the transient absorption (TA) spectrum of $\left[\mathrm{Ru}(\mathrm{bpy})_{2}(\mathrm{BCF})_{2}\right]$ (Figure $7 \mathrm{a}$ ) are fully compatible with an MLCT excited state. Specifically, this spectrum contains two excited-state absorption bands with maxima at 355 and $455 \mathrm{~nm}$ (both attributable to bpy ${ }^{\bullet-}$, see below) as well as a ground-state bleach centered at $395 \mathrm{~nm} .{ }^{89}$ The negative signal around $550 \mathrm{~nm}$ is caused by emission. The bpy $^{\bullet-}$ band of $\left[\mathrm{Ru}(\text { bpy })_{2}(\mathrm{BCF})_{2}\right]$ at $455 \mathrm{~nm}$ appears blueshifted with respect to the analogous band in $\left[\mathrm{Ru}(\mathrm{bpy})_{3}\right]^{2+}$ $\left(\lambda_{\max }=502 \mathrm{~nm}\right),{ }^{90}$ but this is mostly due to overlap with the emission band. In the presence of $50 \mathrm{mM}$ diisopropylethylamine (DiPEA) as a sacrificial reductant, the bpy ${ }^{\bullet-}$-related absorption bands persist for several microseconds (Figure $7 \mathrm{~b}$ ), and the characteristic absorptions of a singly reduced ruthenium bipyridine complex at $515^{90}$ and $355 \mathrm{~nm}$ are readily detectable. ${ }^{91}$ The insets in Figure $7 \mathrm{a}, \mathrm{b}$ show the calculated spin densities of ${ }^{3} \mathrm{MLCT}$-excited $\left[\mathrm{Ru}(\mathrm{bpy})_{2}(\mathrm{BCF})_{2}\right]$ (a) and $\left[\mathrm{Ru}(\mathrm{bpy})_{2}(\mathrm{BCF})_{2}\right]^{-}$(b). In the ${ }^{3} \mathrm{MLCT}$ state, spin density is localized on the $\mathrm{Ru}(\mathrm{III})$ center $(40 \%)$ and the reduced bpy ligand (60\%), whereas in the one-electron reduced form, the spin density is localized exclusively on the reduced ligand, as expected. ${ }^{92}$

The transient absorption spectrum of [Ru$\left.\left(\mathrm{CF}_{3} \mathrm{bpy}\right)_{2}(\mathrm{BCF})_{2}\right]$ (Figure $7 \mathrm{c}$ ) is similar to that of $[\mathrm{Ru}-$ $\left.(\mathrm{bpy})_{2}(\mathrm{BCF})_{2}\right]$ in Figure $7 \mathrm{a}$. Due to the electron-withdrawing $\mathrm{CF}_{3}$ substituents, the MLCT ground-state bleach and the emission of $\left[\mathrm{Ru}\left(\mathrm{CF}_{3} \mathrm{bpy}\right)_{2}(\mathrm{BCF})_{2}\right]$ are red-shifted by $\sim 25 \mathrm{~nm}$ compared to $\left[\mathrm{Ru}(\mathrm{bpy})_{2}(\mathrm{BCF})_{2}\right]$. No transient absorption spectrum of the singly reduced $\left[\mathrm{Ru}\left(\mathrm{CF}_{3} \mathrm{bpy}\right)_{2}(\mathrm{BCF})_{2}\right]^{-}$could be measured due to the instability of this complex in the presence of DiPEA and light. This is not problematic, because $\left[\mathrm{Ru}\left(\mathrm{CF}_{3} \mathrm{bpy}\right)_{2}(\mathrm{BCF})_{2}\right]^{-}$would have only a comparatively modest reducing power $(-0.92 \mathrm{~V}$ vs SCE$)$, and the application potential of this particular species for reductive photocatalysis would be somewhat limited anyway.

\section{Photostability}

Insufficient photostability is a well-known problem for many photosensitizers, and in particular, the prototypical $[\mathrm{Ru}-$ $\left.(\text { bpy })_{3}\right]^{2+}$ complex undergoes rather facile photodegradation. ${ }^{93,94}$ Similar observations have been made for some Ir(III) complexes. ${ }^{95,96}$ Against this background, we investigated the inherent photostability of $\left[\mathrm{Ru}(\mathrm{bpy})_{2}(\mathrm{BCF})_{2}\right]$, $\left[\mathrm{Ru}\left(\mathrm{CF}_{3} \mathrm{bpy}\right)_{2}(\mathrm{BCF})_{2}\right], \mathrm{fac}-\left[\operatorname{Ir}(\mathrm{ppy})_{3}\right]$, and $\left[\mathrm{Ru}(\mathrm{bpy})_{3}\right]^{2+}$ by irradiation of $\mathrm{CH}_{3} \mathrm{CN}$ solutions with a blue continuous-wave (cw) laser (447 nm, $1.1 \mathrm{~W})$. Following a recently described methodology, ${ }^{72,97}$ the absorbance of each solution was adjusted to 0.1 at the excitation wavelength, leading to concentrations of $8.7 \mu \mathrm{M}$ for $\left[\mathrm{Ru}(\mathrm{bpy})_{3}\right]^{2+}, 36 \mu \mathrm{M}$ for $\mathrm{fac}$ $\left[\operatorname{Ir}(\mathrm{ppy})_{3}\right], 32 \mu \mathrm{M}$ for $\left[\mathrm{Ru}\left(\mathrm{CF}_{3} \mathrm{bpy}\right)_{2}(\mathrm{BCF})_{2}\right]$, and $149 \mu \mathrm{M}$ for $\left[\mathrm{Ru}(\mathrm{bpy})_{2}(\mathrm{BCF})_{2}\right]$. The temperature was kept constant at 20 ${ }^{\circ} \mathrm{C}$ during the measurements, and the photoluminescence intensity was monitored continuously in a spectrometer. The change in concentration was calculated from the decrease in luminescence intensity, assuming that these two values are directly proportional to one another (control experiments indicate the absence of emissive decomposition products; see 
$\left[\mathrm{Ru}(\mathrm{bpy})_{2}(\mathrm{BCF})_{2}\right]$

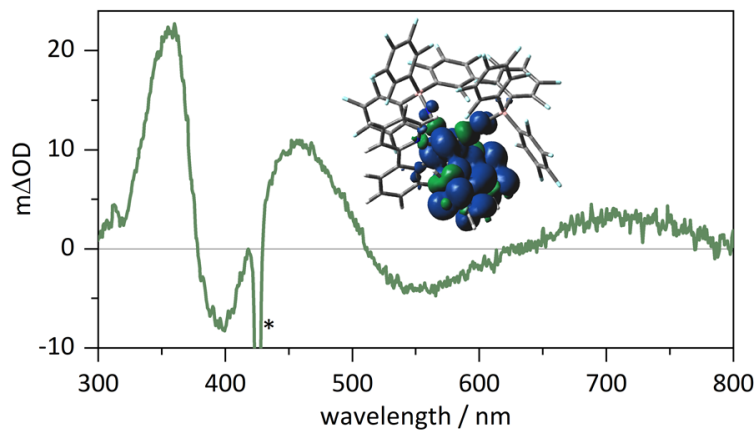

b)

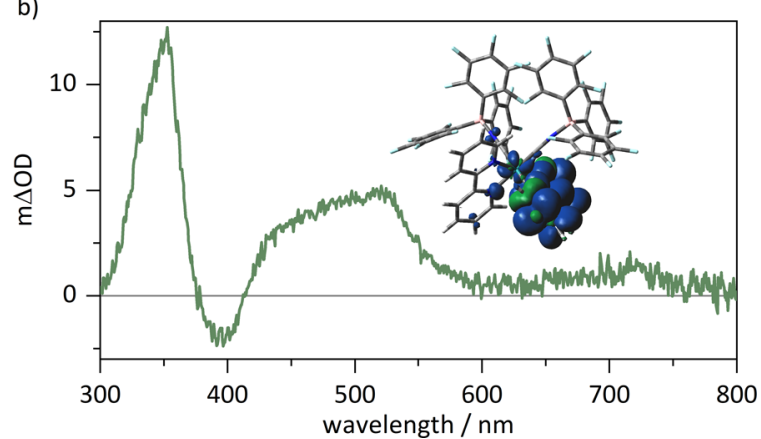

c)

$\left[\mathrm{Ru}\left(\mathrm{CF}_{3} \mathrm{bpy}\right)_{2}(\mathrm{BCF})_{2}\right]$

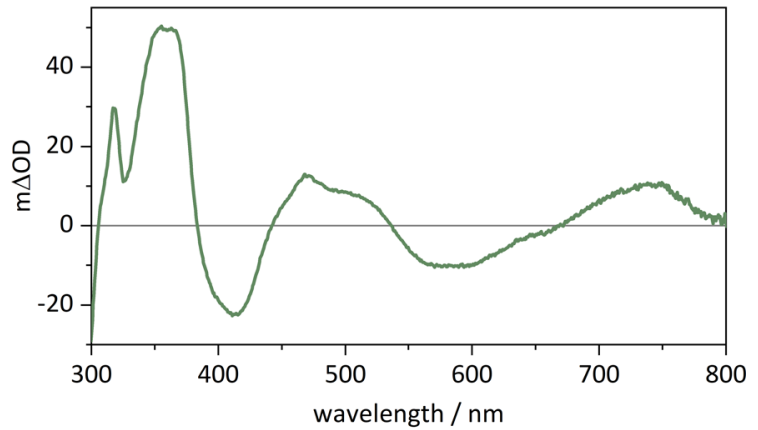

Figure 7. (a) Transient absorption spectrum measured after $425 \mathrm{~nm}$ excitation of a $10^{-5} \mathrm{M}$ solution of $\left[\mathrm{Ru}(\mathrm{bpy})_{2}(\mathrm{BCF})_{2}\right]$ in deaerated $\mathrm{CH}_{3} \mathrm{CN}$ at $20{ }^{\circ} \mathrm{C}$ with laser pulses of $\sim 10 \mathrm{~ns}$ duration. The signals were time-integrated over $10 \mathrm{~ns}$ immediately after excitation. The asterisk marks stray light from the excitation laser pulse. The inset shows the calculated spin densities of the ${ }^{3} \mathrm{MLCT}$ state. (b) Transient absorption spectrum measured after $425 \mathrm{~nm}$ excitation of a solution containing $10^{-5} \mathrm{M}\left[\mathrm{Ru}(\mathrm{bpy})_{2}(\mathrm{BCF})_{2}\right]$ and $50 \mathrm{mM}$ DiPEA with laser pulses of $\sim 10 \mathrm{~ns}$ duration. The signal was recorded with a delay of $100 \mathrm{~ns}$ after the laser pulses and was time-integrated over $200 \mathrm{~ns}$. The inset shows the calculated spin densities of the oneelectron reduced $\left[\mathrm{Ru}(\mathrm{bpy})_{2}(\mathrm{BCF})_{2}\right]$ complex. (c) Transient absorption spectrum measured after $532 \mathrm{~nm}$ excitation of a $10^{-5} \mathrm{M}$ solution of $\left[\mathrm{Ru}\left(\mathrm{CF}_{3} \mathrm{bpy}\right)_{2}(\mathrm{BCF})_{2}\right]$ in deaerated $\mathrm{CH}_{3} \mathrm{CN}$ at $20^{\circ} \mathrm{C}$ with laser pulses of $\sim 10 \mathrm{~ns}$ duration. The signal was time-integrated over $200 \mathrm{~ns}$ immediately after excitation. In the insets, blue color represents positive spin densities, whereas green represents negative spin densities.

red traces in the emission spectra of Figure S36). In Figure 8, the change in concentration as a function of irradiation time is presented. As all samples initially absorbed the same number of photons, this is a good measure to directly compare the

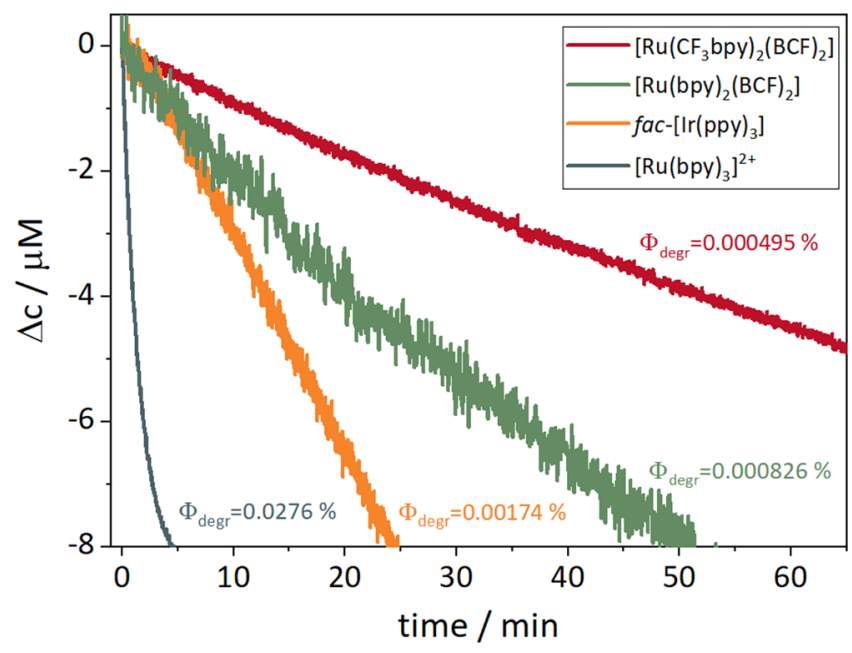

Figure 8. Photostability of $\left[\mathrm{Ru}\left(\mathrm{CF}_{3} \mathrm{bpy}\right)_{2}(\mathrm{BCF})_{2}\right], \quad[\mathrm{Ru}-$ $\left.(\text { bpy })_{2}(\mathrm{BCF})_{2}\right], f a c-\left[\operatorname{Ir}(\text { ppy })_{3}\right]$, and $\left[\mathrm{Ru}(\mathrm{bpy})_{3}\right]^{2+}$ upon irradiation with a blue $\mathrm{cw}$ laser $(447 \mathrm{~nm}, 1.1 \mathrm{~W})$ in argon-saturated $\mathrm{CH}_{3} \mathrm{CN}$ at $20{ }^{\circ} \mathrm{C}$. Concentration changes $(\Delta c)$ were calculated based on photoluminescence intensities as a function of irradiation time; see text and SI page S34 for details. photostabilities of the four complexes; see SI page S34 for details.

Based on the change in concentration, the photodegradation quantum yield $\Phi_{\text {degr }}$, defined here as the number of degraded photosensitizer molecules divided by the number of absorbed photons, was calculated for all four complexes. The number of absorbed photons is directly accessible from the laser power output $(1.1 \mathrm{~W})$ and the known absorbance $(0.1)$ at the irradiation wavelength. The number of decomposed photosensitizer molecules was calculated from the decrease in emission intensity to $90 \%$ of the initial intensity (see SI page S34 for details). This procedure gave the $\Phi_{\text {degr }}$ values in Table 2 , from which it is evident that $\left[\mathrm{Ru}\left(\mathrm{CF}_{3} \mathrm{bpy}\right)_{2}(\mathrm{BCF})_{2}\right]$ is 56 times more photostable than $\left[\mathrm{Ru}(\mathrm{bpy})_{3}\right]^{2+}$, while $[\mathrm{Ru}-$ $\left.(\text { bpy })_{2}(\mathrm{BCF})_{2}\right]$ is 33 times more robust under photoirradiation than $\left[\mathrm{Ru}(\mathrm{bpy})_{3}\right]^{2+}$. In recent multiphoton excitation experiments, a water-soluble variant of $f a c$ - $\left[\operatorname{Ir}(\mathrm{ppy})_{3}\right]$ was particularly photorobust, $^{97,98}$ and against this reference point, the low photodegradation quantum yields of $\left[\mathrm{Ru}\left(\mathrm{CF}_{3} \mathrm{bpy}\right)_{2}(\mathrm{BCF})_{2}\right]$

Table 2. Photodegradation Quantum Yields $\left(\boldsymbol{\Phi}_{\text {degr }}\right)$ and Relative Photostabilities of the Four Complexes from Figure 1 Measured in $\mathrm{CD}_{3} \mathrm{CN}$ at $20{ }^{\circ} \mathrm{C}$

$\begin{array}{lcc} & \Phi_{\text {degr }} / \% & \text { relative photostability } \\ {\left[\mathrm{Ru}\left(\mathrm{CF}_{3} \mathrm{bpy}\right)_{2}(\mathrm{BCF})_{2}\right]} & 4.95 \cdot 10^{-4} & 56 \\ {\left[\mathrm{Ru}(\mathrm{bpy})_{2}(\mathrm{BCF})_{2}\right]} & 8.26 \cdot 10^{-4} & 33 \\ \mathrm{fac}-\left[\mathrm{Ir}(\mathrm{ppy})_{3}\right] & 1.74 \cdot 10^{-3} & 16 \\ {\left[\mathrm{Ru}(\mathrm{bpy})_{3}\right]^{2+}} & 2.76 \cdot 10^{-2} & 1\end{array}$


and $\left[\mathrm{Ru}(\mathrm{bpy})_{2}(\mathrm{BCF})_{2}\right]$ are all the more remarkable. The improved photostabilities of the two isocyanoborato complexes can be rationalized based on the DFT calculations performed for $\left[\mathrm{Ru}(\mathrm{bpy})_{2}(\mathrm{BCF})_{2}\right]$. Photodecomposition of ruthenium(II) polypyridyl complexes typically occurs via MC states with elongated $\mathrm{Ru}-\mathrm{N}$ bonds (similar to how so-called photoCORMs operate), ${ }^{99}$ and prior computational work suggested that computed $\mathrm{Ru}-\mathrm{N}$ bond lengths in these MC states can be used to predict how susceptible to photodegradation a given complex is. ${ }^{92,100}$

Interestingly, the $\mathrm{Ru}-\mathrm{N}$ bond of $\left[\mathrm{Ru}(\mathrm{bpy})_{2}(\mathrm{BCF})_{2}\right]$ elongates only from $2.14 \AA$ in the electronic ground state to $2.36 \AA$ in the lowest ${ }^{3} \mathrm{MC}$ state (see SI page S36), whereas in the case of $\left[\mathrm{Ru}(\mathrm{bpy})_{3}\right]^{2+}$, the respective $\mathrm{Ru}-\mathrm{N}$ bond elongation is much larger, from 2.10 to $2.67 \AA$. Thus, the much-enhanced photostability of $\left[\mathrm{Ru}(\mathrm{bpy})_{2}(\mathrm{BCF})_{2}\right]$ compared to $\left[\mathrm{Ru}(\mathrm{bpy})_{3}\right]^{2+}$ indeed correlates with a significantly weaker distortion in the lowest ${ }^{3} \mathrm{MC}$ excited state.

\section{Energy Transfer Catalysis: trans/cis-Photoisomerization and Photosensitized Ni(II) Cross-Coupling Catalysis}

Given the very favorable photophysical and electrochemical properties of the isocyanoborato complexes, it seemed attractive to explore their application potential in photocatalysis. As a first test reaction, we chose the photoisomerization of trans-methyl cinnamate $\left(E_{\mathrm{T}}=2.38 \mathrm{eV}\right)^{101}$ to its cis-isomer. The latter has a substantially higher triplet energy than its trans-form, and consequently, triplet photosensitization with an appropriate catalyst (with a ${ }^{3} \mathrm{MLCT}$ energy between the triplet energies of the two relevant isomers) is expected to lead to the accumulation of the cisisomer over time. ${ }^{11,102}$ The photoreaction was performed with $83 \mathrm{mmol} \mathrm{L}^{-1}$ trans-methyl cinnamate and $33 \mathrm{mmol} \mathrm{L}^{-1}$ trimethyl(phenyl)silane as an internal standard in the presence of $1 \mathrm{~mol} \%$ of $\left[\mathrm{Ru}(\mathrm{bpy})_{2}(\mathrm{BCF})_{2}\right]$. The photoisomerization was conducted in a sealed NMR tube to prevent undesired side reactions with oxygen, using a $440 \mathrm{~nm}$ LED as an irradiation source.

While only negligible conversion was observed after $2 \mathrm{~h}$ with $\left[\mathrm{Ru}(\mathrm{bpy})_{3}\right]^{2+}$ as a photosensitizer, the new $\left[\mathrm{Ru}(\mathrm{bpy})_{2}(\mathrm{BCF})_{2}\right]$ complex successfully isomerized $70 \%$ of the trans-methyl cinnamate to its cis-form (Figure 9). This shows that the unusually high triplet energy of $\left[\mathrm{Ru}(\mathrm{bpy})_{2}(\mathrm{BCF})_{2}\right]$ is instrumental for successful completion of this reaction. In order to take advantage of the high photostability of $\left[\mathrm{Ru}(\mathrm{bpy})_{2}(\mathrm{BCF})_{2}\right]$, the catalyst loading for this isomerization

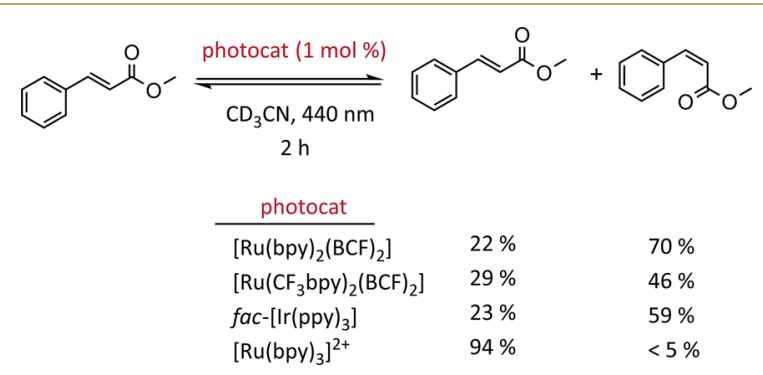

Figure 9. Photoisomerization of methyl cinnamate and relative compositions (determined by ${ }^{1} \mathrm{H}$ NMR spectroscopy with the internal standard trimethyl(phenyl)silane) of the reaction solutions after an irradiation time of $2 \mathrm{~h}$. The reactions were performed in a watercooled reactor under inert atmosphere at room temperature using an LED as the light source. reaction was lowered to $0.02 \mathrm{~mol} \%$. Even under these conditions, $\left[\mathrm{Ru}(\mathrm{bpy})_{2}(\mathrm{BCF})_{2}\right]$ was able to catalyze the trans/ cis-isomerization of methyl cinnamate with a yield of $65 \%$ after a reaction time of $8 \mathrm{~h}$, resulting in a turnover number (TON) greater than 3000 .

The $f a c-\left[\operatorname{Ir}(\mathrm{ppy})_{3}\right]$ complex has a similarly high triplet energy as $\left[\mathrm{Ru}(\mathrm{bpy})_{2}(\mathrm{BCF})_{2}\right]$ (Figure 1 ), yet with this sensitizer, photoisomerization only proceeded with 59\% yield, and non-negligible amounts of a side product were formed. The better performance of $\left[\mathrm{Ru}(\mathrm{bpy})_{2}(\mathrm{BCF})_{2}\right]$ compared to $f a c$ - $\left[\operatorname{Ir}(\mathrm{ppy})_{3}\right]$ is tentatively attributed to the long excited-state lifetime of fac-[Ir(ppy $\left.)_{3}\right](1750 \mathrm{~ns}$, Table 1) compared to $\left[\mathrm{Ru}(\mathrm{bpy})_{2}(\mathrm{BCF})_{2}\right](8.6 \mathrm{~ns}$, Table 1$)$, which leads to a comparatively high steady-state triplet concentration in the case of the $\operatorname{Ir}(\mathrm{III})$ complex that might enable otherwise inefficient bimolecular reactions. A plausible side reaction is the $[2+2]$ cycloaddition, which is known to occur with $\operatorname{Ir}(\mathrm{III})$ photosensitizers. ${ }^{1,103}$ This example shows that despite nearly identical thermodynamics (same triplet energy of $2.50 \mathrm{eV}$ for both photosensitizers, Figure 1), different excited-state lifetimes can affect the reaction outcome in an unanticipated manner. With $\left[\mathrm{Ru}\left(\mathrm{CF}_{3} \mathrm{bpy}\right)_{2}(\mathrm{BCF})_{2}\right]$ as the photosensitizer, the photoisomerization reaction gives a lower yield (46\%), because the triplet energy of that complex is lower $(2.35 \mathrm{eV}$, Figure 1c).

While photoisomerization reactions have received significant attention from the synthetic photochemistry community in recent years, ${ }^{11,102,104}$ the specific example in Figure 9 mainly serves as a simple test reaction to showcase the comparatively high triplet energies of the new isocyanoborato complexes. From a synthetic perspective, there exists a fairly broad range of other reaction types that are attractive targets for energy transfer catalysis. ${ }^{15,105,106}$ One specific example involves the sensitization of nickel-based cross-coupling. ${ }^{107}$ Combined photocatalysis and $\mathrm{Ni}$ catalysis has received significant attention over the past few years and has found application in $\mathrm{C}-\mathrm{C},{ }^{108-112} \mathrm{C}-\mathrm{O},{ }^{13,113,114} \mathrm{C}-\mathrm{S},{ }^{115-117}$ and $\mathrm{C}-\mathrm{N}^{118-120}$ bond-forming reactions. ${ }^{107}$ Many of these cross-coupling reactions rely on electron transfer, but some of them seem to function on the basis of triplet-triplet energy transfer (TTET) from the photosensitizer to the $\mathrm{Ni}$ (II) catalyst. ${ }^{13,107,121}$ For instance, $f a c-\left[\operatorname{Ir}(\mathrm{ppy})_{3}\right]$ has been employed to photosensitize the Ni-catalyzed coupling of aryl halides with carboxylic acids via TTET. ${ }^{13}$ Given that $\left[\mathrm{Ru}(\mathrm{bpy})_{2}(\mathrm{BCF})_{2}\right]$ has the same triplet energy as $f a c$ - $\left[\operatorname{Ir}(\mathrm{ppy})_{3}\right]$ (Figure 1 and Table 1), we anticipated that this isocyanoborato complex would be a suitable photosensitizer for this reaction type. Indeed, $\left[\mathrm{Ru}(\mathrm{bpy})_{2}(\mathrm{BCF})_{2}\right]$ sensitized the Ni-catalyzed coupling of benzoic acid with methyl 4-bromobenzoate in $71 \%$ isolated yield (Figure 10). When using $\left[\mathrm{Ru}(\mathrm{bpy})_{3}\right]^{2+}$ as photosensitizer under identical reaction conditions, only the starting material was isolated, underscoring the importance of a high triplet energy. With $f a c$ - $\left[\operatorname{Ir}(p p y)_{3}\right]$, we only obtained a yield of $50 \%$ under our experimental conditions, though the reaction with this particular sensitizer is known to operate much better under optimized conditions. ${ }^{13}$ Even though a mechanism based on energy transfer was suggested for the Nicatalyzed $\mathrm{C}-\mathrm{O}$ coupling and has been supported by further studies, ${ }^{122}$ recent work reached the conclusion that a mechanism based on a light-independent $\mathrm{Ni}(\mathrm{I}) / \mathrm{Ni}(\mathrm{III})$ interconversion can be operative. ${ }^{13,123-125}$ A plausible catalytic cycle for the TTET mechanism is shown in Figure $10 \mathrm{~b}$, as adapted from previously published mechanistic 
a)
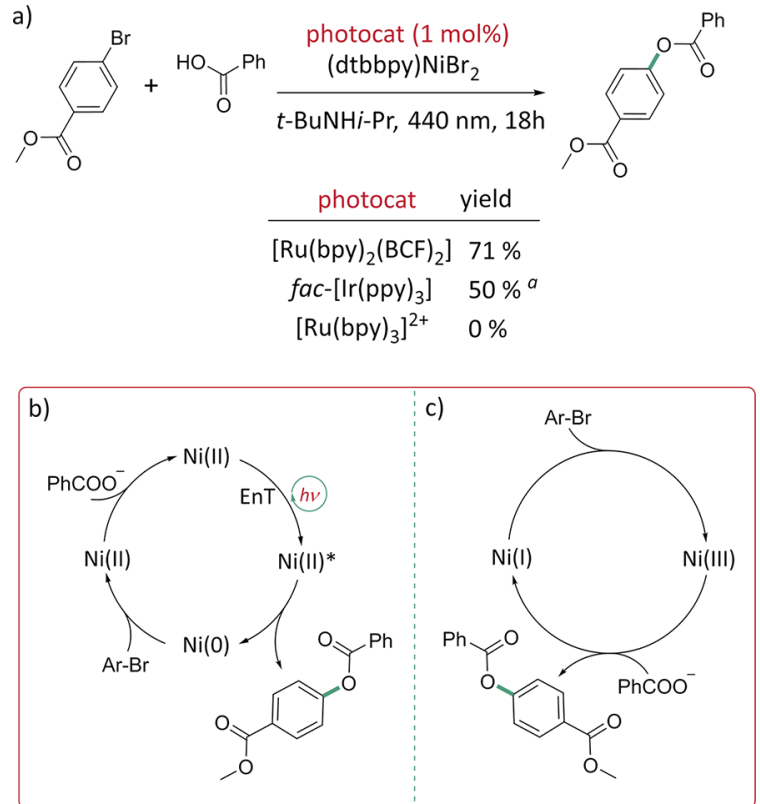

Figure 10. (a) Photosensitized Ni-catalyzed coupling of benzoic acid with methyl 4-bromobenzoate in DMF, and the isolated yields obtained by employing different photosensitizers. (b) Catalytic cycle for the TTET reaction mechanism. (c) Catalytic cycle for the $\mathrm{Ni}(\mathrm{I}) /$ $\mathrm{Ni}$ (III) reaction mechanism. [a]: An isolated yield of $94 \%$ was previously reported. ${ }^{13}$ Under the conditions employed here, we find a yield of $50 \%$.

studies. ${ }^{13,107}$ Oxidative addition of the aryl halide substrate to a $\mathrm{Ni}(0)$ precursor and exchange of a halogenide ligand by the carboxylate reaction partner leads to the $\mathrm{Ni}$ (II) intermediate at the top of the cycle. Reductive elimination from the electronic ground state of $\mathrm{Ni}$ (II) complexes is difficult ${ }^{126,127}$ but can be promoted by excitation to a ${ }^{3} \mathrm{MC}$ state via TTET from a suitable photosensitizer. ${ }^{13,121}$

Alternatively, based on the above-mentioned more recent mechanistic studies of nickel catalysis, ${ }^{113,123-125}$ it is possible that the catalytic cycle in Figure 10c plays a non-negligible role. In this scenario, $\mathrm{Ni}(\mathrm{I})$ species are generated via a photoinduced electron transfer from $\left[\mathrm{Ru}(\mathrm{bpy})_{2}(\mathrm{BCF})_{2}\right]$ to the $\mathrm{Ni}$ (II) precursor. Subsequent oxidative addition of the aryl halide substrate leads to a $\mathrm{Ni}(\mathrm{III})$ intermediate, which can cross-couple the aryl halide and the carboxylate. The reductive elimination step regenerates the catalyst in the $\mathrm{Ni}(\mathrm{I})$ state.

So far, mostly iridium-based photosensitizers have been used for this reaction type, while ruthenium(II) complexes did not have sufficiently high triplet energies or were not reducing enough. Our work demonstrates that isocyanoborylation makes $\mathrm{Ru}(\mathrm{II})$ compounds amenable to nickel-catalyzed crosscoupling chemistry.

\section{Reductive Photocatalysis: Pinacol Coupling}

To explore the potential application of $\mathrm{Ru}(\mathrm{II})$ isocyanoborato complexes in reductive photocatalysis, we focused on $[\mathrm{Ru}-$ $\left.(\mathrm{bpy})_{2}(\mathrm{BCF})_{2}\right]$ and chose the light-driven pinacol coupling of benzaldehyde (Figure 11a) as a simple benchmark reaction for comparison with the prototypical $\left[\mathrm{Ru}(\mathrm{bpy})_{3}\right]^{2+}$ photosensitizer. This reaction commonly proceeds via single-electron transfer (SET) to the substrate and subsequent coupling of two benzaldehyde radicals. ${ }^{128-131}$ With $\left[\mathrm{Ru}(\mathrm{bpy})_{3}\right]^{2+}$ as a photocatalyst and DiPEA as a reductant, no reaction was observed due to the rather modest reducing power $(-1.30 \mathrm{~V}$ vs $\mathrm{SCE}$ ) of $\left[\mathrm{Ru}(\mathrm{bpy})_{3}\right]^{+}$(formed after electron transfer from DiPEA to photoexcited $\left.\left[\mathrm{Ru}(\mathrm{bpy})_{3}\right]^{2+}\right)$, in line with earlier reports. $^{128,132}$ By contrast, $\left[\mathrm{Ru}(\text { bpy })_{2}(\mathrm{BCF})_{2}\right]$ gave $87 \% \mathrm{NMR}$ yield of the pinacol-coupled product as a mixture of the mesoand DL-isomers $(0.9: 1)$ after an irradiation time of $2 \mathrm{~h}$. Evidently, the slightly higher reducing power of $[\mathrm{Ru}-$ $\left.(\text { bpy })_{2}(\mathrm{BCF})_{2}\right]^{-}(-1.46 \mathrm{~V}$ vs $\mathrm{SCE})$ enables ketyl radical anion formation and efficient substrate turnover.

From a mechanistic perspective, it is interesting to note that reductive ${ }^{3} \mathrm{MLCT}$ quenching of $\left[\mathrm{Ru}(\mathrm{bpy})_{2}(\mathrm{BCF})_{2}\right]$ by DiPEA is more than 100 times faster compared to $\left[\mathrm{Ru}(\mathrm{bpy})_{3}\right]^{2+}$ (Figure $1 \mathrm{lb}$ ). The respective rate constants are $k_{\mathrm{q}}=1.3 \cdot 10^{9}$ $\mathrm{M}^{-1} \mathrm{~s}^{-1}$ for $\left[\mathrm{Ru}(\mathrm{bpy})_{2}(\mathrm{BCF})_{2}\right]$ and $k_{\mathrm{q}}=7.4 \cdot 10^{6} \mathrm{M}^{-1} \mathrm{~s}^{-1}$ for $\left[\mathrm{Ru}(\text { bpy })_{3}\right]^{2+}$ (Table 3 ), determined from Stern-Volmer quenching experiments (see SI page S32 for details). This remarkable difference in rate constants is due to the higher excited-state reduction potential of $\left[\mathrm{Ru}(\mathrm{bpy})_{2}(\mathrm{BCF})_{2}\right](1.04 \mathrm{~V}$ vs $\mathrm{SCE})$ compared to $\left[\mathrm{Ru}(\mathrm{bpy})_{3}\right]^{2+}(0.82 \mathrm{~V}$ vs $\mathrm{SCE})$, which results in a larger driving force for reductive excited-state quenching by DiPEA. The excited-state quenching efficiencies $(\eta)$ of $\left[\mathrm{Ru}(\mathrm{bpy})_{2}(\mathrm{BCF})_{2}\right]$ and $\left[\mathrm{Ru}(\mathrm{bpy})_{3}\right]^{2+}$ as a function of DiPEA concentration are shown in Figure $11 \mathrm{~b}$. The two curves were calculated using the expression ${ }^{133}$
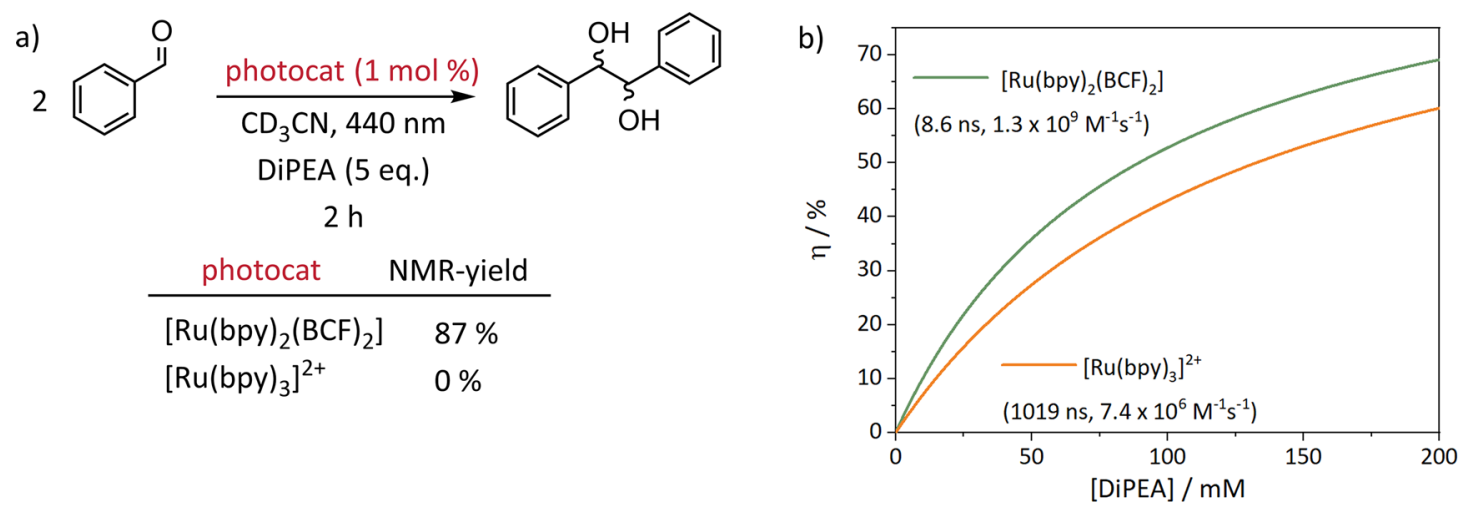

Figure 11. (a) Pinacol coupling of benzaldehyde and NMR yields obtained with the different photocatalysts. The reaction was performed in a water-cooled reactor at room temperature. (b) Calculated excited-state quenching efficiencies $(\eta)$ as a function of DiPEA concentration for $\left[\mathrm{Ru}(\mathrm{bpy})_{2}(\mathrm{BCF})_{2}\right]$ (green trace) and $\left[\mathrm{Ru}(\mathrm{bpy})_{3}\right]^{2+}$ (orange trace). Natural ${ }^{3} \mathrm{MLCT}$ lifetimes $\left(\tau_{0}\right)$ and rate constants $\left(k_{\mathrm{q}}\right)$ for reductive quenching by DiPEA are given in the insets. 
Table 3. Excited-State Quenching Constants of the Four Complexes from Figure 1 with Methyl Cinnamate $\left(k_{\mathrm{q}}\right.$, Cinn $)$, Benzaldehyde $\left(k_{\mathrm{q}, \text { Benz }}\right)$, and DiPEA $\left(k_{\mathrm{q}, \text { DiPEA }}\right)$ Determined in Dry, Deaerated $\mathrm{CH}_{3} \mathrm{CN}$ at $20{ }^{\circ} \mathrm{C}$

\begin{tabular}{|c|c|c|c|}
\hline & \multicolumn{3}{|c|}{ quenching constants } \\
\hline & $k_{\mathrm{q}, \mathrm{Cinn}} / \mathrm{M}^{-1} \mathrm{~s}^{-1}$ & $k_{\mathrm{q}, \text { Benz }} / \mathrm{M}^{-1} \mathrm{~s}^{-1}$ & $k_{\mathrm{q}, \text { DiPEA }} / \mathrm{M}^{-1} \mathrm{~s}^{-1}$ \\
\hline$\left[\mathrm{Ru}(\mathrm{bpy})_{2}(\mathrm{BCF})_{2}\right]$ & $3.58 \cdot 10^{8}$ & - & $1.3 \cdot 10^{9 a}$ \\
\hline$\left[\mathrm{Ru}\left(\mathrm{CF}_{3} \mathrm{bpy}\right)_{2}(\mathrm{BCF})_{2}\right]$ & $6.31 \cdot 10^{6}$ & - & - \\
\hline$f a c-\left[\operatorname{Ir}(\mathrm{ppy})_{3}\right]$ & $1.25 \cdot 10^{9}$ & $3.54 \cdot 10^{7}$ & $<10^{6}$ \\
\hline$\left[\mathrm{Ru}(\mathrm{bpy})_{3}\right]^{2+}$ & $<10^{5}$ & - & $7.4 \cdot 10^{6}$ \\
\hline
\end{tabular}

$$
\eta=\left(\left(\tau_{0}-\tau\right) / \tau_{0}\right) \cdot 100 \%
$$

where $\tau_{0}$ is the natural (unquenched) ${ }^{3} \mathrm{MLCT}$ excited-state lifetime and $\tau$ is the lifetime in the presence of a given DiPEA concentration ([DiPEA $]$ ), calculated from $\tau^{-1}=\tau_{0}^{-1}+k_{\mathrm{q}} \times$ [DiPEA]. The data in Figure $11 \mathrm{~b}$ leads to the counterintuitive finding that the $\left[\mathrm{Ru}(\mathrm{bpy})_{2}(\mathrm{BCF})_{2}\right]$ complex undergoes reductive quenching by DiPEA more efficiently than $[\mathrm{Ru}-$ $\left.(\mathrm{bpy})_{3}\right]^{2+}$, even though its natural lifetime is approximately a factor of 120 shorter ( 8.6 compared to $1019 \mathrm{~ns}$, Table 1).

\section{Oxidative Photocatalysis: C-C Coupling Reaction}

After it was established that $\mathrm{Ru}(\mathrm{II})$ isocyanoborato complexes are amenable to energy transfer catalysis and reductive photoredox catalysis, it seemed interesting to also explore their application potential in oxidative photoredox chemistry. For this purpose, we concentrated on $\left[\mathrm{Ru}\left(\mathrm{CF}_{3} \mathrm{bpy}\right)_{2}(\mathrm{BCF})_{2}\right]$ with its electron-withdrawing $\mathrm{CF}_{3}$ substituents. As a model reaction, we chose the oxidative decarboxylation of $\mathrm{Cbz}-$ proline $(\mathrm{Cbz}=$ benzyloxycarbonyl $)$ and subsequent addition of the resulting $\alpha$-amino alkyl radical to the ethyl maleate Michael acceptor (Figure 12). ${ }^{76}$

This reaction was performed on a preparative scale with $\left[\mathrm{Ru}\left(\mathrm{CF}_{3} \mathrm{bpy}\right)_{2}(\mathrm{BCF})_{2}\right]$ as the photocatalyst (SI page S29),

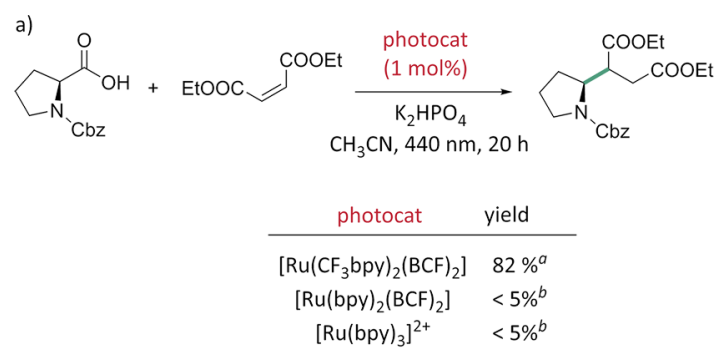

b)

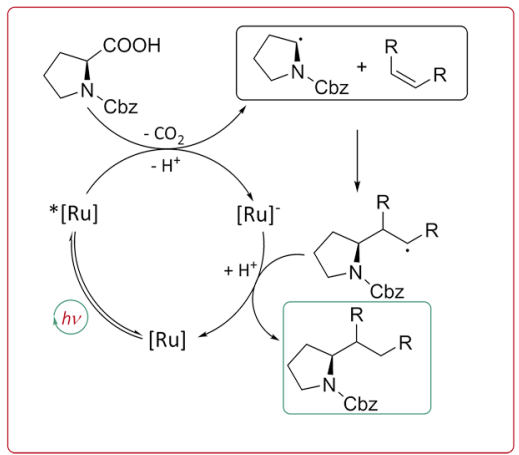

Figure 12. Oxidative decarboxylation and subsequent coupling of Cbz-proline $\alpha$-amino alkyl radical to ethyl maleate $(\mathrm{R}=\mathrm{COOEt})$ with different photocatalysts (a) and the catalytic cycle of this reaction (b). [a]: Isolated yield. [b]: Conversion based on ethyl maleate consumption (see SI page S56 for details). ${ }^{76}$ resulting in an isolated yield of $82 \%$. When $\left[\mathrm{Ru}(\mathrm{bpy})_{3}\right]^{2+}$ or $\left[\mathrm{Ru}(\mathrm{bpy})_{2}(\mathrm{BCF})_{2}\right]$ was used, only minor amounts of ethyl maleate were consumed (less than $5 \%$ ), and no product signals appeared in the ${ }^{1} \mathrm{H}$ NMR spectrum. This is attributed to the fact that a careful balance of redox potentials between the ground and excited state of the photocatalyst is required for the reaction in Figure 12a.

On the one hand, the photoexcited complex (designated $*[\mathrm{Ru}]$ in the catalytic cycle in Figure 12b) must be sufficiently oxidizing for the initial decarboxylation step (for a closely related substrate $E_{1 / 2}=0.95 \mathrm{~V}$ vs SCE has been reported), ${ }^{134}$ and on the other hand, its one-electron reduced form (designated $[\mathrm{Ru}]^{-}$) needs to be a sufficiently strong electron donor to enable the (proton-coupled) reduction of the $\beta$ amino alkyl radical to the final product. ${ }^{135}$ With an excitedstate reduction potential $E^{0}\left(*[\mathrm{Ru}] /[\mathrm{Ru}]^{-}\right)$of $1.43 \mathrm{~V}$ vs SCE (Figure $3 \mathrm{~b}$ ) and a ground-state potential $E^{0}\left([\mathrm{Ru}]^{-} /[\mathrm{Ru}]\right)$ of $-0.92 \mathrm{~V}$ vs $\mathrm{SCE}$ (Figure $3 \mathrm{~b}),\left[\mathrm{Ru}\left(\mathrm{CF}_{3} \mathrm{bpy}\right)_{2}(\mathrm{BCF})_{2}\right]$ fulfills both of these requirements. By contrast, $\left[\mathrm{Ru}(\mathrm{bpy})_{2}(\mathrm{BCF})_{2}\right]$ and $\left[\mathrm{Ru}(\mathrm{bpy})_{3}\right]^{2+}$ are not sufficiently potent photooxidants and as such are unable to promote the initial decarboxylation step in efficient manner.

\section{CONCLUSIONS}

Second coordination sphere interactions between hydrogenbond donating solvents and ruthenium(II) and iron(II) cyanide complexes have long been known to exert a strong influence on their photophysical properties. ${ }^{83,136-140}$ Herein, we exploit the nonlabile nature of the Lewis acid-base interaction between $\mathrm{B}\left(\mathrm{C}_{6} \mathrm{~F}_{5}\right)_{3}$ and the peripheral $\mathrm{N}$ atoms of $\mathrm{Ru}(\mathrm{II})$-coordinated cyanide ligands to access uncommon photophysics and photochemistry. While second coordination sphere effects are of key importance in bioinorganic chemistry and energy-related catalysis, ${ }^{141,142}$ it seems that this concept has received rather limited attention in the design of new photoactive d-metal compounds, ${ }^{64,143-150}$ at least among single-component (i.e., mononuclear) systems.

In the $\left[\mathrm{Ru}(\mathrm{bpy})_{2}(\mathrm{BCF})_{2}\right]$ complex, the energy of the emissive ${ }^{3} \mathrm{MLCT}$ state is raised by nearly $0.4 \mathrm{eV}$ relative to $\left[\mathrm{Ru}(\mathrm{bpy})_{3}\right]^{2+}$ (Table 1$)$, making this compound amenable to photoisomerization reactions and sensitized nickel-catalyzed cross-couplings that usually require iridium(III) photosensitizers with high triplet energies. The benchmark reactions of methyl cinnamate photoisomerization (Figure 9) and the C$\mathrm{O}$ coupling between benzoic acid and methyl 4-bromobenzoate (Figure 10) illustrate the application potential of $\left[\mathrm{Ru}(\mathrm{bpy})_{2}(\mathrm{BCF})_{2}\right]$ and related isocyanoborato complexes for energy transfer catalysis. The increased ${ }^{3} \mathrm{MLCT}$ energy furthermore facilitates reductive excited-state quenching (Figure 11) and provides access to thermodynamically 
challenging photoreductions that are unattainable with $[\mathrm{Ru}-$ $\left.(\text { bpy })_{3}\right]^{2+}$ and its congeners.

The increased ${ }^{3} \mathrm{MLCT}$ energy of $\left[\mathrm{Ru}(\mathrm{bpy})_{2}(\mathrm{BCF})_{2}\right]$ decreases the activation barrier for internal conversion into nearby ${ }^{3} \mathrm{MC}$ states (Figure 6), thereby enhancing nonradiative excited-state relaxation. However, the resulting ${ }^{3} \mathrm{MLCT}$ lifetime is still sufficiently long for efficient bimolecular reactions, and the undesirable effect of enhanced nonradiative relaxation can be counteracted by introducing trifluoromethyl substituents at the bpy ligands. The resulting [Ru$\left.\left(\mathrm{CF}_{3} \text { bpy }\right)_{2}(\mathrm{BCF})_{2}\right]$ complex exhibits a microsecond ${ }^{3} \mathrm{MLCT}$ lifetime paired with a photoluminescence quantum yield of $12.8 \%$ (Table 1) and furthermore is a potent photooxidant capable of triggering oxidative decarboxylation reactions (Figure 12).

Under intense $(1.1 \mathrm{~W})$ blue $(447 \mathrm{~nm})$ laser irradiation in acetonitrile, the isocyanoborato complexes are remarkably photorobust. For instance, the inherent photostability of $\left[\mathrm{Ru}\left(\mathrm{CF}_{3} \mathrm{bpy}\right)_{2}(\mathrm{BCF})_{2}\right]$ is 56 times greater under these conditions than for $\left[\mathrm{Ru}(\mathrm{bpy})_{3}\right]^{2+}$ and 3.5 times greater than for $f a c-\left[\operatorname{Ir}(\mathrm{ppy})_{3}\right]$.

Despite remarkable recent advances in the development of photoactive base metal complexes, ${ }^{20,21}$ ruthenium(II) and iridium(III) compounds remain among the most reliable workhorses in organic synthetic photochemistry and artificial photosynthesis. Our work demonstrates how undesirable nonradiative relaxation events and photodegradation pathways in ruthenium(II) sensitizers can be suppressed and how their photophysical and electrochemical properties can be adapted to increasingly challenging applications in energy transfer and photoredox catalysis. More generally, this study illustrates the significant potential of second coordination sphere effects for the design of new photoactive d-metal complexes that are able to meet the current demands of applications in lighting, sensing, photodynamic therapy, photocatalysis, and solar energy conversion. ${ }^{151-154}$

\section{ASSOCIATED CONTENT}

\section{Supporting Information}

The Supporting Information is available free of charge at https://pubs.acs.org/doi/10.1021/jacsau.1c00137.

Synthetic protocols and characterization data, X-ray crystallography data, electrochemical characterization, equipment and methods, NMR data, details to photostability studies (PDF)

X-ray crystallographic data for $\Lambda$ - $\left[\mathrm{Ru}(\mathrm{bpy})_{2}(\mathrm{BCF})_{2}\right]$ (CIF)

X-ray crystallographic data for $\Delta$-[Ru( $\left.\left(\mathrm{CF}_{3} \mathrm{bpy}\right)_{2}(\mathrm{BCF})_{2}\right]$ (CIF)

\section{AUTHOR INFORMATION}

\section{Corresponding Author}

Oliver S. Wenger - Department of Chemistry, University of Basel, 4056 Basel, Switzerland; 10 orcid.org/0000-0002 0739-0553; Email: oliver.wenger@unibas.ch

\section{Authors}

Lucius Schmid - Department of Chemistry, University of Basel, 4056 Basel, Switzerland; 이 orcid.org/0000-00015803-6979
Christoph Kerzig - Department of Chemistry, Johannes Gutenberg University Mainz, 55128 Mainz, Germany; (1) orcid.org/0000-0002-1026-1146

Alessandro Prescimone - Department of Chemistry, University of Basel, 4058 Basel, Switzerland; 이이이.org/ 0000-0002-3631-5210

Complete contact information is available at: https://pubs.acs.org/10.1021/jacsau.1c00137

\section{Funding}

This work was funded by the Swiss National Science Foundation through grant number 200021_178760 and by the Chemical Industry Funds (Liebig fellowship to C. K.).

Notes

The authors declare no competing financial interest.

\section{ABBREVIATIONS}

MLCT, metal-to-ligand charge transfer; bpy, 2,2'-bipyridine; ppy, 2-phenylpyridine; TTET, triplet-triplet energy transfer; $\mathrm{BCF}, \mathrm{CNB}\left(\mathrm{C}_{6} \mathrm{~F}_{5}\right)_{3} ; \mathrm{E}_{\mathrm{T}}$, triplet energy; HOMO, highest occupied molecular orbital; LUMO, lowest unoccupied molecular orbital; DiPEA, diisopropylethylamine; cw, continuous wave; LED, light-emitting diode; SET, single-electron transfer

\section{REFERENCES}

(1) Strieth-Kalthoff, F.; James, M. J.; Teders, M.; Pitzer, L.; Glorius, F. Energy transfer catalysis mediated by visible light: principles, applications, directions. Chem. Soc. Rev. 2018, 47, 7190-7202.

(2) Strieth-Kalthoff, F.; Glorius, F. Triplet energy transfer photocatalysis: unlocking the next level. Chem. 2020, 6, 1888-1903.

(3) Ghogare, A. A.; Greer, A. Using singlet oxygen to synthesize natural products and drugs. Chem. Rev. 2016, 116, 9994-10034.

(4) Lu, Z.; Yoon, T. P. Visible light photocatalysis of [2+2] styrene cycloadditions by energy transfer. Angew. Chem. Int. Ed. 2012, 51, 10329-10332.

(5) Hurtley, A. E.; Lu, Z.; Yoon, T. P. [2+2] cycloaddition of 1,3dienes by visible light photocatalysis. Angew. Chem., Int. Ed. 2014, 53, 8991-8994.

(6) Tröster, A.; Alonso, R.; Bauer, A.; Bach, T. Enantioselective Intermolecular $[2+2]$ Photocycloaddition Reactions of 2(1H)Quinolones Induced by Visible Light Irradiation. J. Am. Chem. Soc. 2016, 138, 7808-7811.

(7) Skubi, K. L.; Kidd, J. B.; Jung, H.; Guzei, I. A.; Baik, M.-H.; Yoon, T. P. Enantioselective Excited-State Photoreactions Controlled by a Chiral Hydrogen-Bonding Iridium Sensitizer. J. Am. Chem. Soc. 2017, 139, 17186-17192.

(8) Hörmann, F. M.; Kerzig, C.; Chung, T. S.; Bauer, A.; Wenger, O. S.; Bach, T. Triplet Energy Transfer from Ruthenium Complexes to Chiral Eniminium Ions: Enantioselective Synthesis of Cyclobutanecarbaldehydes by $[2+2]$ Photocycloaddition. Angew. Chem., Int. Ed. 2020, 59, 9659-9668.

(9) Murray, P. R. D.; Bussink, W. M. M.; Davies, G. H. M.; van der Mei, F. W.; Antropow, A. H.; Edwards, J. T.; D’Agostino, L. A.; Ellis, J. M.; Hamann, L. G.; Romanov-Michailidis, F.; Knowles, R. R. Intermolecular Crossed [2+2] Cycloaddition Promoted by VisibleLight Triplet Photosensitization: Expedient Access to Polysubstituted 2-Oxaspiro[3.3] heptanes. J. Am. Chem. Soc. 2021, 143, 4055.

(10) Higgins, R. F.; Fatur, S. M.; Damrauer, N. H.; Ferreira, E. M.; Rappé, A. K.; Shores, M. P. Detection of an Energy-Transfer Pathway in Cr-Photoredox Catalysis. ACS Catal. 2018, 8, 9216-9225.

(11) Molloy, J. J.; Schäfer, M.; Wienhold, M.; Morack, T.; Daniliuc, C. G.; Gilmour, R. Boron-enabled geometric isomerization of alkenes via selective energy-transfer catalysis. Science 2020, 369, 302-306. 
(12) Xu, B.; Troian-Gautier, L.; Dykstra, R.; Martin, R. T.; Gutierrez, O.; Tambar, U. K. Photocatalyzed diastereoselective isomerization of cinnamyl chlorides to cyclopropanes. J. Am. Chem. Soc. 2020, 142, 6206-6215.

(13) Welin, E. R.; Le, C.; Arias-Rotondo, D. M.; McCusker, J. K.; MacMillan, D. W. C. Photosensitized, Energy Transfer-mediated Organometallic Catalysis through Electronically Excited Nickel(II). Science 2017, 355, 380-385.

(14) Zhang, L.; Si, X.; Rominger, F.; Hashmi, A. S. K. Visible-LightInduced Radical Carbo-Cyclization/gem-Diborylation through Triplet Energy Transfer between a Gold Catalyst and Aryl Iodides. J. Am. Chem. Soc. 2020, 142, 10485-10493.

(15) Teders, M.; Henkel, C.; Anhäuser, L.; Strieth-Kalthoff, F.; Gómez-Suárez, A.; Kleinmans, R.; Kahnt, A.; Rentmeister, A.; Guldi, D.; Glorius, F. The energy-transfer-enabled biocompatible disulfideene reaction. Nat. Chem. 2018, 10, 981-988.

(16) Manna, M. K.; Shokri, S.; Wiederrecht, G. P.; Gosztola, D. J.; Ayitou, A. J.-L. New perspectives for triplet-triplet annihilation based photon upconversion using all-organic energy donor \& acceptor chromophores. Chem. Commun. 2018, 54, 5809-5818.

(17) Teegardin, K.; Day, J. I.; Chan, J.; Weaver, J. Advances in photocatalysis: A microreview of visible light mediated ruthenium and iridium catalyzed organic transformations. Org. Process Res. Dev. 2016, 20, 1156-1163.

(18) Mills, I. N.; Porras, J. A.; Bernhard, S. Judicious Design of Cationic, Cyclometalated Ir(III) Complexes for Photochemical Energy Conversion and Optoelectronics. Acc. Chem. Res. 2018, 51, 352-364.

(19) Bevernaegie, R.; Wehlin, S. A. M.; Elias, B.; Troian-Gautier, L. A Roadmap Towards Visible Light Mediated Electron Transfer Chemistry with Iridium(III) Complexes. ChemPhotoChem. 2021, 5, 217.

(20) Wenger, O. S. Photoactive Complexes with Earth-Abundant Metals. J. Am. Chem. Soc. 2018, 140, 13522-13533.

(21) Förster, C.; Heinze, K. Photophysics and photochemistry with Earth-abundant metals - fundamentals and concepts. Chem. Soc. Rev. 2020, 49, 1057-1070.

(22) Zhang, Y.; Lee, T. S.; Favale, J. M.; Leary, D. C.; Petersen, J. L.; Scholes, G. D.; Castellano, F. N.; Milsmann, C. Delayed Fluorescence from a Zirconium(IV) Photosensitizer with Ligand-to-Metal ChargeTransfer Excited States. Nat. Chem. 2020, 12, 345-352.

(23) Paulus, B. C.; Adelman, S. L.; Jamula, L. L.; McCusker, J. K. Leveraging excited-state coherence for synthetic control of ultrafast dynamics. Nature 2020, 582, 214-218.

(24) Magnuson, A.; Anderlund, M.; Johansson, O.; Lindblad, P.; Lomoth, R.; Polivka, T.; Ott, S.; Stensjö, K.; Styring, S.; Sundström, V.; Hammarström, L. Biomimetic and microbial approaches to solar fuel generation. Acc. Chem. Res. 2009, 42, 1899-1909.

(25) Marzo, L.; Pagire, S. K.; Reiser, O.; König, B. Visible-Light Photocatalysis: Does It Make a Difference in Organic Synthesis? Angew. Chem., Int. Ed. 2018, 57, 10034-10072.

(26) Buzzetti, L.; Crisenza, G. E. M.; Melchiorre, P. Mechanistic Studies in Photocatalysis. Angew. Chem., Int. Ed. 2019, 58, 37303747.

(27) Moll, J.; Wang, C.; Päpcke, A.; Förster, C.; Resch-Genger, U.; Lochbrunner, S.; Heinze, K. Green-Light Activation of Push-Pull Ruthenium(II) Complexes. Chem. - Eur. J. 2020, 26, 6820-6832.

(28) Yang, C.-H.; Mauro, M.; Polo, F.; Watanabe, S.; Muenster, I.; Fröhlich, R.; De Cola, L. Deep-Blue-Emitting Heteroleptic Iridium(III) Complexes Suited for Highly Efficient Phosphorescent OLEDs. Chem. Mater. 2012, 24, 3684-3695.

(29) Yersin, H.; Rausch, A. F.; Czerwieniec, R.; Hofbeck, T.; Fischer, $\mathrm{T}$. The triplet state of organo-transition metal compounds. Triplet harvesting and singlet harvesting for efficient OLEDs. Coord. Chem. Rev. 2011, 255, 2622-2652.

(30) Rota Martir, D.; Zysman-Colman, E. Supramolecular iridium(III) assemblies. Coord. Chem. Rev. 2018, 364, 86-117.

(31) Kaufmann, M.; Müller, C.; Cullen, A. A.; Brandon, M. P.; Dietzek, B.; Pryce, M. T. Photophysics of Ruthenium(II) Complexes with Thiazole $\pi$-Extended Dipyridophenazine Ligands. Inorg. Chem. 2021, 60, 760-773.

(32) Pal, A. K.; Nag, S.; Ferreira, J. G.; Brochery, V.; La Ganga, G.; Santoro, A.; Serroni, S.; Campagna, S.; Hanan, G. S. Red-Emitting $\left[\mathrm{Ru}(\text { bpy })_{2}(\mathrm{~N}-\mathrm{N})\right]^{2+}$ Photosensitizers: Emission from a Ruthenium(II) to $2,2^{\prime}$-Bipyridine ${ }^{3}$ MLCT State in the Presence of Neutral Ancillary "Super Donor" Ligands. Inorg. Chem. 2014, 53, 1679-1689.

(33) Bevernaegie, R.; Wehlin, S. A. M.; Piechota, E. J.; Abraham, M.; Philouze, C.; Meyer, G. J.; Elias, B.; Troian-Gautier, L. Improved Visible Light Absorption of Potent Iridium(III) Photo-oxidants for Excited-State Electron Transfer Chemistry. J. Am. Chem. Soc. 2020, $142,2732-2737$.

(34) Lo, K. K.-W.; Li, S. P.-Y.; Zhang, K. Y. Development of luminescent iridium(III) polypyridine complexes as chemical and biological probes. New J. Chem. 2011, 35, 265-287.

(35) White, J. K.; Schmehl, R. H.; Turro, C. An overview of photosubstitution reactions of $\mathrm{Ru}(\mathrm{II})$ imine complexes and their application in photobiology and photodynamic therapy. Inorg. Chim. Acta 2017, 454, 7-20.

(36) Isakov, D.; Giereth, R.; Nauroozi, D.; Tschierlei, S.; Rau, S. Two Emissive Long-Lived Excited States of an Imidazole-Functionalized Ruthenium Dipyridophenazine Complex. Inorg. Chem. 2019, $58,12646-12653$.

(37) Karges, J.; Kuang, S.; Maschietto, F.; Blacque, O.; Ciofini, I.; Chao, H.; Gasser, G. Rationally designed ruthenium complexes for 1and 2-photon photodynamic therapy. Nat. Commun. 2020, 11, 3262.

(38) Soupart, A.; Alary, F.; Heully, J.-L.; Elliott, P. I. P.; Dixon, I. M. Recent Progress in Ligand Photorelease Reaction Mechanisms: Theoretical Insights Focusing on $\mathrm{Ru}(\mathrm{II}){ }^{3} \mathrm{MC}$ States. Coord. Chem. Rev. 2020, 408, 213184.

(39) Caporale, C.; Massi, M. Cyclometalated iridium(III) complexes for life science. Coord. Chem. Rev. 2018, 363, 71-91.

(40) Yoon, S.; Teets, T. S. Red to near-infrared phosphorescent Ir(III) complexes with electron-rich chelating ligands. Chem. Commun. 2021, 57, 1975-1988.

(41) Taylor, J. O.; Pižl, M.; Kloz, M.; Rebarz, M.; McCusker, C. E.; McCusker, J. K.; Záliš, S.; Hartl, F.; Vlček, A. Optical and Infrared Spectroelectrochemical Studies of CN-Substituted Bipyridyl Complexes of Ruthenium(II). Inorg. Chem. 2021, 60, 3514.

(42) Draper, S. M.; Gregg, D. J.; Schofield, E. R.; Browne, W. R.; Duati, M.; Vos, J. G.; Passaniti, P. Complexed Nitrogen Heterosuperbenzene: The Coordinating Properties of a Remarkable Ligand. J. Am. Chem. Soc. 2004, 126, 8694-8701.

(43) Pascual-Leone, N.; Conklin, E.; Andrade, G. A.; Rosenthal, J.; Young, E. R. Role of Electrostatics in Influencing the Pathway by Which the Excited State of $\left[\mathrm{Ru}(\mathrm{bpy})_{3}\right]^{2+}$ is Deactivated by Ferrocene Derivatives. J. Phys. Chem. A 2019, 123, 7673-7682.

(44) Wang, J.; Lu, Y.; McCarthy, W.; Conway-Kenny, R.; Twamley, B.; Zhao, J.; Draper, S. M. Novel ruthenium and iridium complexes of $\mathrm{N}$-substituted carbazole as triplet photosensitisers. Chem. Commun. 2018, 54, 1073-1076.

(45) Zhou, L.; Wei, F.; Xiang, J.; Li, H.; Li, C.; Zhang, P.; Liu, C.; Gong, P.; Cai, L.; Wong, K. M.-C. Enhancing the ROS generation ability of a rhodamine-decorated iridium(III) complex by ligand regulation for endoplasmic reticulum-targeted photodynamic therapy. Chem. Sci. 2020, 11, 12212-12220.

(46) Rentschler, M.; Schmid, M.-A.; Frey, W.; Tschierlei, S.; Karnahl, M. Multidentate phenanthroline ligands containing additional donor moieties and their resulting $\mathrm{Cu}(\mathrm{I})$ and $\mathrm{Ru}(\mathrm{II})$ photosensitizers: A comparative study. Inorg. Chem. 2020, 59, 14762-14771.

(47) Juris, A.; Balzani, V.; Barigelletti, F.; Campagna, S.; Belser, P.; von Zelewsky, A. $\mathrm{Ru}(\mathrm{II})$ polypyridine complexes: photophysics, photochemistry, eletrochemistry, and chemiluminescence. Coord. Chem. Rev. 1988, 84, 85-277.

(48) Suzuki, T.; Kuchiyama, T.; Kishi, S.; Kaizaki, S.; Takagi, H. D.; Kato, M. Ruthenium(II) Complexes Containing 8(Dimethylphosphino)quinoline $\left(\mathrm{Me}_{2} \mathrm{Pqn}\right)$ : Preparation, Crystal Structures, and Electrochemical and Spectroscopic Properties of 
$\left[\mathrm{Ru}(\text { bpy or phen })_{3-\mathrm{n}}\left(\mathrm{Me}_{2} \mathrm{Pqn}\right)\right]\left(\mathrm{PF}_{6}\right)_{2}\left(\mathrm{bpy}=2,2^{\prime}-\right.$ Bipyridine; phen $=$ 1,10-Phenanthroline; $n=1,2$, or 3). Inorg. Chem. 2003, 42, 785-795. (49) Myrick, M. L.; De Armond, M. K. High-energy metal to ligand charge-transfer states in ruthenium-diimine complexes. J. Phys. Chem. 1989, 93, 7099-7107.

(50) Dixon, I. M.; Lebon, E.; Sutra, P.; Igau, A. Luminescent ruthenium-polypyridine complexes \& phosphorus ligands: anything but a simple story. Chem. Soc. Rev. 2009, 38, 1621-1634.

(51) Indelli, M. T.; Bignozzi, C. A.; Marconi, A.; Scandola, F. Ruthenium(II) 2,2'-bipyridine complexes containing methyl isocyanide ligands. Extreme effects of nonchromophoric ligands on excitedstate properties. J. Am. Chem. Soc. 1988, 110, 7381-7386.

(52) McNicholas, B. J.; Grubbs, R. H.; Winkler, J. R.; Gray, H. B.; Despagnet-Ayoub, E. Tuning the formal potential of ferrocyanide over a 2.1 V range. Chem. Sci. 2019, 10, 3623-3626.

(53) Ngo, D. X.; Del Ciello, S. A.; Barth, A. T.; Hadt, R. G.; Grubbs, R. H.; Gray, H. B.; McNicholas, B. J. Electronic Structures, Spectroscopy, and Electrochemistry of $\left[\mathrm{M}(\text { diimine })\left(\mathrm{CN}-\mathrm{BR}_{3}\right)_{4}\right]^{2-}$ $\left(\mathrm{M}=\mathrm{Fe}, \mathrm{Ru} ; \mathrm{R}=\mathrm{Ph}, \mathrm{C}_{6} \mathrm{~F}_{5}\right)$ Complexes. Inorg. Chem. 2020, 59, 9594-9604.

(54) Ngo, D. X.; Del Ciello, S. A.; McNicholas, B. J.; Sanders, B. C.; Fajardo, J.; Gray, H. B.; Winkler, J. R. Cyano-ambivalence: Spectroscopy and photophysics of $\left[\mathrm{Ru}(\text { diimine })\left(\mathrm{CN}-\mathrm{BR}_{3}\right)_{4}\right]^{2-}$ complexes. Polyhedron 2020, 188, 114692.

(55) Chan, K.-C.; Chu, W.-K.; Yiu, S.-M.; Ko, C.-C. Synthesis, characterization, photophysics and electrochemical study of luminescent iridium(III) complexes with isocyanoborate ligands. Dalton Trans. 2015, 44, 15135-15144.

(56) Chu, W. K.; Wei, X. G.; Yiu, S. M.; Ko, C. C.; Lau, K. C. Strongly Phosphorescent Neutral Rhenium(I) Isocyanoborato Complexes: Synthesis, Characterization, and Photophysical, Electrochemical, and Computational studies. Chem. - Eur. J. 2015, 21, 2603-2612.

(57) Chu, W.-K.; Ko, C.-C.; Chan, K.-C.; Yiu, S.-M.; Wong, F.-L.; Lee, C.-S.; Roy, V. A. L. A Simple Design for Strongly Emissive SkyBlue Phosphorescent Neutral Rhenium Complexes: Synthesis, Photophysics, and Electroluminescent Devices. Chem. Mater. 2014, $26,2544-2550$.

(58) Xiao, Y.; Chu, W.-K.; Ng, C.-O.; Cheng, S.-C.; Tse, M.-K.; Yiu, S.-M.; Ko, C.-C. Design and Synthesis of Luminescent Bis(isocyanoborato) Rhenate(I) Complexes as a Selective Sensor for Cyanide Anion. Organometallics 2020, 39, 2135-2141.

(59) Chan, K. C.; Tong, K. M.; Cheng, S. C.; Ng, C. O.; Yiu, S. M.; Ko, C. C. Design of Luminescent Isocyano Rhenium(I) Complexes: Photophysics and Effects of the Ancillary Ligands. Inorg. Chem. 2018, 57, 13963-13972.

(60) Chakkaradhari, G.; Eskelinen, T.; Degbe, C.; Belyaev, A.; Melnikov, A. S.; Grachova, E. V.; Tunik, S. P.; Hirva, P.; Koshevoy, I. O. Oligophosphine-thiocyanate Copper(I) and Silver(I) Complexes and Their Borane Derivatives Showing Delayed Fluorescence. Inorg. Chem. 2019, 58, 3646-3660.

(61) Chu, W.-K.; Yiu, S.-M.; Ko, C.-C. Neutral Luminescent Bis(bipyridyl) Osmium(II) Complexes with Improved Phosphorescent Properties. Organometallics 2014, 33, 6771-6777.

(62) Lancaster, S. J.; Walker, D. A.; Thornton-Pett, M.; Bochmann, M. New weakly coordinating counter anions for high activity polymerisation catalysts: $\left[\left(\mathrm{C}_{6} \mathrm{~F}_{5}\right)_{3} \mathrm{~B}-\mathrm{CN}-\mathrm{B}\left(\mathrm{C}_{6} \mathrm{~F}_{5}\right)_{3}\right]^{-}$and $[\mathrm{Ni}\{\mathrm{CNB}-$ $\left.\left.\left(\mathrm{C}_{6} \mathrm{~F}_{5}\right)_{3}\right\}_{4}\right]^{2-}$. Chem. Commun. 1999, 1533-1534.

(63) Zhou, J.; Lancaster, S. J.; Walker, D. A.; Beck, S.; ThorntonPett, M.; Bochmann, M. Synthesis, structures, and reactivity of weakly coordinating anions with delocalized borate structure: the assessment of anion effects in metallocene polymerization catalysts. J. Am. Chem. Soc. 2001, 123, 223-237.

(64) Na, H.; Maity, A.; Teets, T. S. Postsynthetic systematic electronic tuning of organoplatinum photosensitizers via secondary coordination sphere interactions. Organometallics 2016, 35, 22672274.

(65) Chan, K.-C.; Cheng, S.-C.; Lo, L. T.-L.; Yiu, S.-M.; Ko, C.-C. Luminescent Charge-Neutral Copper(I) Phenanthroline Complexes with Isocyanoborate Ligand. Eur. J. Inorg. Chem. 2018, 2018, 897903.

(66) Fajardo, J.; Schwan, J.; Kramer, W. W.; Takase, M. K.; Winkler, J. R.; Gray, H. B. Third-Generation W(CNAr $)_{6}$ Photoreductants (CNAr $=$ Fused-Ring and Alkynyl-Bridged Arylisocyanides $)$. Inorg. Chem. 2021, 60, 3481.

(67) Sattler, W.; Henling, L. M.; Winkler, J. R.; Gray, H. B. Bespoke Photoreductants: Tungsten Arylisocyanides. J. Am. Chem. Soc. 2015, $137,1198-1205$.

(68) Sattler, W.; Ener, M. E.; Blakemore, J. D.; Rachford, A. A.; LaBeaume, P. J.; Thackeray, J. W.; Cameron, J. F.; Winkler, J. R.; Gray, H. B. Generation of Powerful Tungsten Reductants by Visible Light Excitation. J. Am. Chem. Soc. 2013, 135, 10614-10617.

(69) Kvapilová, H.; Sattler, W.; Sattler, A.; Sazanovich, I. V.; Clark, I. P.; Towrie, M.; Gray, H. B.; Zálišs, S.; Vlček, A. Electronic Excited States of Tungsten(0) Arylisocyanides. Inorg. Chem. 2015, 54, 85188528.

(70) Büldt, L. A.; Guo, X.; Prescimone, A.; Wenger, O. S. A Molybdenum(0) Isocyanide Analogue of $\mathrm{Ru}\left(2,2^{\prime} \text {-Bipyridine }\right)_{3}{ }^{2+}: \mathrm{A}$ Strong Reductant for Photoredox Catalysis. Angew. Chem., Int. Ed. 2016, 55, 11247-11250.

(71) Herr, P.; Glaser, F.; Büldt, L. A.; Larsen, C. B.; Wenger, O. S. Long-Lived, Strongly Emissive, and Highly Reducing Excited States in $\mathrm{Mo}(0)$ Complexes with Chelating Isocyanides. J. Am. Chem. Soc. 2019, 141, 14394-14402.

(72) Bilger, J. B.; Kerzig, C.; Larsen, C. B.; Wenger, O. S. A Photorobust $\mathrm{Mo}(0)$ Complex Mimicking $\left[\mathrm{Os}\left(2,2^{\prime} \text {-bipyridine }\right)_{3}\right]^{2+}$ and Its Application in Red-to-Blue Upconversion. J. Am. Chem. Soc. 2021, 143, 1651-1663.

(73) Büldt, L. A.; Guo, X.; Vogel, R.; Prescimone, A.; Wenger, O. S. A Tris(diisocyanide)chromium(0) Complex Is a Luminescent Analog of $\mathrm{Fe}\left(2,2^{\prime} \text {-Bipyridine }\right)_{3}{ }^{2+}$. J. Am. Chem. Soc. 2017, 139, 985-992.

(74) Aihara, Y.; Sato, K.; Shinozaki, K. Optical Resolution, Determination of Absolute Configuration, and Photoracemization of cis- $\mathrm{RuL}_{2}(\mathrm{CN})_{2}\left(\mathrm{~L}=2,2^{\prime}\right.$-Bipyridine and Its Analogues). Inorg. Chem. 2016, 55, 8387-8395.

(75) Zilate, B.; Fischer, C.; Sparr, C. Design and application of aminoacridinium organophotoredox catalysts. Chem. Commun. 2020, $56,1767-1775$

(76) Joshi-Pangu, A.; Lévesque, F.; Roth, H. G.; Oliver, S. F.; Campeau, L.-C.; Nicewicz, D.; DiRocco, D. A. Acridinium-Based Photocatalysts: A Sustainable Option in Photoredox Catalysis. J. Org. Chem. 2016, 81, 7244-7249.

(77) Damrauer, N. H.; Boussie, T. R.; Devenney, M.; McCusker, J. K. Effects of Intraligand Electron Delocalization, Steric Tuning, and Excited-State Vibronic Coupling on the Photophysics of ArylSubstituted Bipyridyl Complexes of Ru(II). J. Am. Chem. Soc. 1997, $119,8253-8268$.

(78) Caspar, J. V.; Meyer, T. J. Application of the energy gap law to nonradiative, excited-state decay. J. Phys. Chem. 1983, 87, 952-957.

(79) Zhang, W.; Gaffney, K. J. Mechanistic studies of photoinduced spin crossover and electron transfer in inorganic complexes. Acc. Chem. Res. 2015, 48, 1140-1148.

(80) Zhang, K.; Ash, R.; Girolami, G. S.; Vura-Weis, J. Tracking the Metal-Centered Triplet in Photoinduced Spin Crossover of $\mathrm{Fe}$ (phen) ${ }_{3}{ }^{2+}$ with Tabletop Femtosecond M-Edge X-ray Absorption Near-Edge Structure Spectroscopy. J. Am. Chem. Soc. 2019, 141, $17180-17188$.

(81) Duchanois, T.; Liu, L.; Pastore, M.; Monari, A.; Cebrián, C.; Trolez, Y.; Darari, M.; Magra, K.; Francés-Monerris, A.; Domenichini, E.; Beley, M.; Assfeld, X.; Haacke, S.; Gros, P. NHC-Based Iron Sensitizers for DSSCs. Inorganics 2018, 6, 63.

(82) Sun, Q.; Dereka, B.; Vauthey, E.; Lawson Daku, L. M.; Hauser, A. Ultrafast transient IR spectroscopy and DFT calculations of ruthenium(II) polypyridyl complexes. Chem. Sci. 2017, 8, 223-230.

(83) Kjær, K. S.; Kunnus, K.; Harlang, T. C. B.; Van Driel, T. B.; Ledbetter, K.; Hartsock, R. W.; Reinhard, M. E.; Koroidov, S.; Li, L.; Laursen, M. G.; Biasin, E.; Hansen, F. B.; Vester, P.; Christensen, M.; Haldrup, K.; Nielsen, M. M.; Chabera, P.; Liu, Y.; Tatsuno, H.; 
Timm, C.; Uhlig, J.; Sundstöm, V.; Németh, Z.; Szemes, D. S.; Bajnóczi, E.; Vankó, G.; Alonso-Mori, R.; Glownia, J. M.; Nelson, S.; Sikorski, M.; Sokaras, D.; Lemke, H. T.; Canton, S. E.; Wärnmark, K.; Persson, P.; Cordones, A. A.; Gaffney, K. J. Solvent control of charge transfer excited state relaxation pathways in $\left[\mathrm{Fe}\left(2,2^{\prime}\right.\right.$-bipyridine $)$ $\left.(\mathrm{CN})_{4}\right]^{2-}$. Phys. Chem. Chem. Phys. 2018, 20, 4238-4249.

(84) Fatur, S. M.; Shepard, S. G.; Higgins, R. F.; Shores, M. P.; Damrauer, N. H. A Synthetically Tunable System To Control MLCT Excited-State Lifetimes and Spin States in Iron(II) Polypyridines. J. Am. Chem. Soc. 2017, 139, 4493-4505.

(85) Indelli, M. T.; Bignozzi, C. A.; Scandola, F.; Collin, J.-P. Design of Long-Lived $\mathrm{Ru}(\mathrm{II})$ Terpyridine MLCT States. Tricyano Terpyridine Complexes. Inorg. Chem. 1998, 37, 6084-6089.

(86) Arias-Rotondo, D. M.; McCusker, J. K. The photophysics of photoredox catalysis: a roadmap for catalyst design. Chem. Soc. Rev. 2016, 45, 5803-5820.

(87) Roundhill, D. M. Photochemistry and Photophysics of Metal Complexes; Plenum Press: New York, 1994.

(88) Suzuki, K.; Kobayashi, A.; Kaneko, S.; Takehira, K.; Yoshihara, T.; Ishida, H.; Shiina, Y.; Oishi, S.; Tobita, S. Reevaluation of Absolute Luminescence Quantum Yields of Standard Solutions using a Spectrometer with an Integrating Sphere and a Back-Thinned CCD Detector. Phys. Chem. Chem. Phys. 2009, 11, 9850-9860.

(89) Heath, G. A.; Yellowlees, L. J.; Braterman, P. S. Spectroelectrochemical studies on tris-bipyridyl ruthenium complexes; ultraviolet, visible, and near-infrared spectra of the series $[\mathrm{Ru}-$ (bipyridyl) $\left.]_{3}\right]^{2+/ 1+/ 0 / 1-}$. J. Chem. Soc., Chem. Commun. 1981, 287.

(90) Mulazzani, Q. G.; Emmi, S.; Fuochi, P. G.; Hoffman, M. Z.; Venturi, $M$. On the nature of tris $\left(2,2^{\prime}\right.$-bipyridine $)$ ruthenium $(1+)$ ion in aqueous solution. J. Am. Chem. Soc. 1978, 100, 981-983.

(91) Rivarola, C. R.; Bertolotti, S. G.; Previtali, C. M. Photoreduction of $\mathrm{Ru}(\mathrm{bpy})_{3}{ }^{2+}$ by amines in aqueous solution. Kinetics characterization of a long-lived nonemitting excited state. Photochem. Photobiol. 2006, 82, 213-218.

(92) Garino, C.; Terenzi, A.; Barone, G.; Salassa, L. Teaching Inorganic Photophysics and Photochemistry with Three Ruthenium(II) Polypyridyl Complexes: A Computer-Based Exercise. J. Chem. Educ. 2016, 93, 292-298.

(93) Bachmann, C.; Probst, B.; Guttentag, M.; Alberto, R. Ascorbate as an electron relay between an irreversible electron donor and $\mathrm{Ru}(\mathrm{II})$ or Re(I) photosensitizers. Chem. Commun. 2014, 50, 6737-6739.

(94) Krishnan, C. V.; Creutz, C.; Mahajan, D.; Schwarz, H. A.; Sutin, $\mathrm{N}$. Homogeneous catalysis of the photoreduction of water by visible light. 3. Mediation by polypyridine complexes of ruthenium(II) and cobalt(II). Isr. J. Chem. 1982, 22, 98-106.

(95) Connell, T. U.; Fraser, C. L.; Czyz, M. L.; Smith, Z. M.; Hayne, D. J.; Doeven, E. H.; Agugiaro, J.; Wilson, D. J. D.; Adcock, J. L.; Scully, A. D.; Gómez, D. E.; Barnett, N. W.; Polyzos, A.; Francis, P. S. The Tandem Photoredox Catalysis Mechanism of $\left[\operatorname{Ir}(\mathrm{ppy})_{2}(\mathrm{dtb}-\right.$ bpy) $]^{+}$Enabling Access to Energy Demanding Organic Substrates. J. Am. Chem. Soc. 2019, 141, 17646-17658.

(96) Schmidbauer, S.; Hohenleutner, A.; König, B. Studies on the photodegradation of red, green and blue phosphorescent OLED emitters. Beilstein J. Org. Chem. 2013, 9, 2088-2096.

(97) Kerzig, C.; Guo, X.; Wenger, O. S. Unexpected Hydrated Electron Source for Preparative Visible-Light Driven Photoredox Catalysis. J. Am. Chem. Soc. 2019, 141, 2122-2127.

(98) Kerzig, C.; Wenger, O. S. Reactivity control of a photocatalytic system by changing the light intensity. Chem. Sci. 2019, 10, 1102311029.

(99) Ford, P. C. Metal complex strategies for photo-uncaging the small molecule bioregulators nitric oxide and carbon monoxide. Coord. Chem. Rev. 2018, 376, 548-564.

(100) Soupart, A.; Alary, F.; Heully, J. L.; Elliott, P. I. P.; Dixon, I. M. Theoretical Study of the Full Photosolvolysis Mechanism of $\left[\mathrm{Ru}(\mathrm{bpy})_{3}\right]^{2+}$ : Providing a General Mechanistic Roadmap for the Photochemistry of $\left[\mathrm{Ru}\left(\mathrm{N}^{\wedge} \mathrm{N}\right)_{3}\right]^{2+}$-Type Complexes toward Both Cis and Trans Photoproducts. Inorg. Chem. 2020, 59, 14679-14695.
(101) Montalti, M.; Credi, A.; Prodi, L.; Gandolfi, M. T. Handbook of Photochemistry, 3rd ed.; CRC/Taylor \& Francis: Boca Raton, 2006.

(102) Metternich, J.; Gilmour, R. Photocatalytic E $\rightarrow \mathrm{Z}$ isomerization of alkenes. Synlett 2016, 27, 2541-2552.

(103) Becker, M. R.; Wearing, E. R.; Schindler, C. S. Synthesis of azetidines via visible-light-mediated intermolecular $[2+2]$ photocycloadditions. Nat. Chem. 2020, 12, 898-905.

(104) Singh, K.; Staig, S. J.; Weaver, J. D. Facile synthesis of Zalkenes via uphill catalysis. J. Am. Chem. Soc. 2014, 136, 5275-5278.

(105) Hölzl-Hobmeier, A.; Bauer, A.; Silva, A. V.; Huber, S. M.; Bannwarth, C.; Bach, T. Catalytic deracemization of chiral allenes by sensitized excitation with visible light. Nature 2018, 564, 240-243.

(106) Blum, T. R.; Miller, Z. D.; Bates, D. M.; Guzei, I. A.; Yoon, T. P. Enantioselective photochemistry through Lewis acid-catalyzed triplet energy transfer. Science 2016, 354, 1391-1395.

(107) Wenger, O. S. Photoactive nickel complexes in cross-coupling catalysis. Chem. - Eur. J. 2021, 27, 2270-2278.

(108) Zuo, Z.; Ahneman, D. T.; Chu, L.; Terrett, J. A.; Doyle, A. G.; MacMillan, D. W. C. Dual catalysis. Merging photoredox with nickel catalysis: coupling of $\alpha$-carboxyl $\mathrm{sp}^{3}$-carbons with aryl halides. Science 2014, 345, 437-440.

(109) Gutierrez, O.; Tellis, J. C.; Primer, D. N.; Molander, G. A.; Kozlowski, M. C. Nickel-catalyzed cross-coupling of photoredoxgenerated radicals: uncovering a general manifold for stereoconvergence in nickel-catalyzed cross-couplings. J. Am. Chem. Soc. 2015, 137, 4896-4899.

(110) Zuo, Z.; Cong, H.; Li, W.; Choi, J.; Fu, G. C.; MacMillan, D. W. C. Enantioselective Decarboxylative Arylation of $\alpha$-Amino Acids via the Merger of Photoredox and Nickel Catalysis. J. Am. Chem. Soc. 2016, 138, 1832-1835.

(111) Shields, B. J.; Kudisch, B.; Scholes, G. D.; Doyle, A. G. LongLived Charge-Transfer States of Nickel(II) Aryl Halide Complexes Facilitate Bimolecular Photoinduced Electron Transfer. J. Am. Chem. Soc. 2018, 140, 3035-3039.

(112) Tellis, J. C.; Primer, D. N.; Molander, G. A. Single-Electron Transmetalation in Organoboron Cross-coupling by Photoredox/ Nickel Dual Catalysis. Science 2014, 345, 433-436.

(113) Sun, R.; Qin, Y.; Ruccolo, S.; Schnedermann, C.; Costentin, C.; Nocera, D. G. Elucidation of a Redox-Mediated Reaction Cycle for Nickel-Catalyzed Cross Coupling. J. Am. Chem. Soc. 2019, 141, 89-93.

(114) Terrett, J. A.; Cuthbertson, J. D.; Shurtleff, V. W.; MacMillan, D. W. C. Switching on elusive organometallic mechanisms with photoredox catalysis. Nature 2015, 524, 330-334.

(115) Yue, H.; Zhu, C.; Rueping, M. Cross-Coupling of Sodium Sulfinates with Aryl, Heteroaryl, and Vinyl Halides by Nickel/ Photoredox Dual Catalysis. Angew. Chem. 2018, 130, 1385-1389.

(116) Jouffroy, M.; Kelly, C. B.; Molander, G. A. Thioetherification via photoredox/nickel dual catalysis. Org. Lett. 2016, 18, 876-879.

(117) Oderinde, M. S.; Frenette, M.; Robbins, D. W.; Aquila, B.; Johannes, J. W. Photoredox Mediated Nickel Catalyzed CrossCoupling of Thiols With Aryl and Heteroaryl Iodides via Thiyl Radicals. J. Am. Chem. Soc. 2016, 138, 1760-1763.

(118) Corcoran, E. B.; Pirnot, M. T.; Lin, S.; Dreher, S. D.; DiRocco, D. A.; Davies, I. W.; Buchwald, S. L.; MacMillan, D. W. C. Aryl amination using ligand-free $\mathrm{Ni}(\mathrm{II})$ salts and photoredox catalysis. Science 2016, 353, 279-283.

(119) Tasker, S. Z.; Jamison, T. F. Highly Regioselective Indoline Synthesis under Nickel/Photoredox Dual Catalysis. J. Am. Chem. Soc. 2015, 137, 9531-9534.

(120) Kudisch, M.; Lim, C.-H.; Thordarson, P.; Miyake, G. M. Energy Transfer to Ni-Amine Complexes in Dual Catalytic, LightDriven C-N Cross-Coupling Reactions. J. Am. Chem. Soc. 2019, 141, 19479-19486.

(121) Ting, S. I.; Garakyaraghi, S.; Taliaferro, C. M.; Shields, B. J.; Scholes, G. D.; Castellano, F. N.; Doyle, A. G. ${ }^{3}$ d-d Excited States of $\mathrm{Ni}(\mathrm{II})$ Complexes Relevant to Photoredox Catalysis: Spectroscopic Identification and Mechanistic Implications. J. Am. Chem. Soc. 2020, $142,5800-5810$. 
(122) Tian, L.; Till, N. A.; Kudisch, B.; MacMillan, D. W. C.; Scholes, G. D. Transient Absorption Spectroscopy Offers Mechanistic Insights for an Iridium/Nickel-Catalyzed C-O Coupling. J. Am. Chem. Soc. 2020, 142, 4555-4559.

(123) Sun, R.; Qin, Y.; Nocera, D. G. General Paradigm in Photoredox Nickel-Catalyzed Cross-Coupling Allows for Light-Free Access to Reactivity. Angew. Chem., Int. Ed. 2020, 59, 9527-9533.

(124) Qin, Y.; Sun, R.; Gianoulis, N. P.; Nocera, D. G. Photoredox Nickel-Catalyzed C-S Cross-Coupling: Mechanism, Kinetics, and Generalization. J. Am. Chem. Soc. 2021, 143, 2005-2015.

(125) Till, N. A.; Tian, L.; Dong, Z.; Scholes, G. D.; MacMillan, D. W. C. Mechanistic Analysis of Metallaphotoredox C-N Coupling: Photocatalysis Initiates and Perpetuates $\mathrm{Ni}(\mathrm{I}) / \mathrm{Ni}(\mathrm{III})$ Coupling Activity. J. Am. Chem. Soc. 2020, 142, 15830-15841.

(126) Koo, K.; Hillhouse, G. L. Carbon-Nitrogen Bond Formation by Reductive Elimination from Nickel(II) Amido Alkyl Complexes. Organometallics 1995, 14, 4421-4423.

(127) Lin, B. L.; Clough, C. R.; Hillhouse, G. L. Interactions of aziridines with nickel complexes: oxidative-addition and reductiveelimination reactions that break and make C-N bonds. J. Am. Chem. Soc. 2002, 124, 2890-2891.

(128) Nakajima, M.; Fava, E.; Loescher, S.; Jiang, Z.; Rueping, M. Photoredox-Catalyzed Reductive Coupling of Aldehydes, Ketones, and Imines with Visible Light. Angew. Chem., Int. Ed. 2015, 54, 88288832.

(129) Caron, A.; Morin, É.; Collins, S. K. Bifunctional Copper-Based Photocatalyst for Reductive Pinacol-Type Couplings. ACS Catal. 2019, 9, 9458

(130) Tarantino, K. T.; Liu, P.; Knowles, R. R. Catalytic ketyl-olefin cyclizations enabled by proton-coupled electron transfer. J. Am. Chem. Soc. 2013, 135, 10022-10025.

(131) Lee, K. N.; Ngai, M.-Y. Recent developments in transitionmetal photoredox-catalysed reactions of carbonyl derivatives. Chem. Commun. 2017, 53, 13093-13112.

(132) Rouch, W. D.; Zhang, M.; McCulla, R. D. Conjugated polymers as photoredox catalysts: a new catalytic system using visible light to promote aryl aldehyde pinacol couplings. Tetrahedron Lett. 2012, 53, 4942-4945.

(133) Glaser, F.; Kerzig, C.; Wenger, O. S. Multi-Photon Excitation in Photoredox Catalysis: Concepts, Applications, Methods. Angew. Chem., Int. Ed. 2020, 59, 10266-10284.

(134) Zuo, Z.; MacMillan, D. W. C. Decarboxylative arylation of $\alpha$ amino acids via photoredox catalysis: a one-step conversion of biomass to drug pharmacophore. J. Am. Chem. Soc. 2014, 136, 52575260.

(135) Speckmeier, E.; Fischer, T. G.; Zeitler, K. A Toolbox Approach To Construct Broadly Applicable Metal-Free Catalysts for Photoredox Chemistry: Deliberate Tuning of Redox Potentials and Importance of Halogens in Donor-Acceptor Cyanoarenes. J. Am. Chem. Soc. 2018, 140, 15353-15365.

(136) Scandola, F.; Indelli, M. T. Second sphere donor acceptor interactions in excited states of coordination compounds. Ruthenium(II) bipyridine cyano complexes. Pure Appl. Chem. 1988, 60, 973980.

(137) Kjær, K. S.; Zhang, W.; Alonso-Mori, R.; Bergmann, U.; Chollet, M.; Hadt, R. G.; Hartsock, R. W.; Harlang, T.; Kroll, T.; Kubiček, K.; Lemke, H. T.; Liang, H. W.; Liu, Y.; Nielsen, M. M.; Robinson, J. S.; Solomon, E. I.; Sokaras, D.; van Driel, T. B.; Weng, T.-C.; Zhu, D.; Persson, P.; Wärnmark, K.; Sundström, V.; Gaffney, K. $\mathrm{J}$. Ligand manipulation of charge transfer excited state relaxation and spin crossover in $\left[\mathrm{Fe}\left(2,2^{\prime} \text {-bipyridine }\right)_{2}(\mathrm{CN})_{2}\right]$. Struct. Dyn. 2017, 4, 044030 .

(138) Zhang, W.; Kjær, K. S.; Alonso-Mori, R.; Bergmann, U.; Chollet, M.; Fredin, L. A.; Hadt, R. G.; Hartsock, R. W.; Harlang, T.; Kroll, T.; Kubiček, K.; Lemke, H. T.; Liang, H. W.; Liu, Y.; Nielsen, M. M.; Persson, P.; Robinson, J. S.; Solomon, E. I.; Sun, Z.; Sokaras, D.; van Driel, T. B.; Weng, T.-C.; Zhu, D.; Wärnmark, K.; Sundström, V.; Gaffney, K. J. Manipulating Charge Transfer Excited State
Relaxation and Spin Crossover in Iron Coordination Complexes with Ligand Substitution. Chem. Sci. 2017, 8, 515-523.

(139) Indelli, M. T.; Ghirotti, M.; Prodi, A.; Chiorboli, C.; Scandola, F.; McClenaghan, N. D.; Puntoriero, F.; Campagna, S. Solvent Switching of Intramolecular Energy Transfer in Bichromophoric Systems: Photophysics of (2,2'-Bipyridine)tetracyanoruthenate(II)/ Pyrenyl Complexes. Inorg. Chem. 2003, 42, 5489-5497.

(140) Balzani, V.; Sabbatini, N.; Scandola, F. "Second-sphere" photochemistry and photophysics of coordination compounds. Chem. Rev. 1986, 86, 319-337.

(141) Wang, W.-H.; Hull, J. F.; Muckerman, J. T.; Fujita, E.; Himeda, Y. Second-coordination-sphere and electronic effects enhance iridium(III)-catalyzed homogeneous hydrogenation of carbon dioxide in water near ambient temperature and pressure. Energy Environ. Sci. 2012, 5, 7923.

(142) Rakowski DuBois, M.; DuBois, D. L. The roles of the first and second coordination spheres in the design of molecular catalysts for $\mathrm{H}_{2}$ production and oxidation. Chem. Soc. Rev. 2009, 38, 62-72.

(143) Rommel, S. A.; Sorsche, D.; Rau, S. A supramolecular H-bond driven light switch sensor for small anions. Dalton Trans. 2016, 45, 74-77.

(144) Pannwitz, A.; Poirier, S.; Bélanger-Desmarais, N.; Prescimone, A.; Wenger, O. S.; Reber, C. Controlling second coordination sphere effects in luminescent ruthenium complexes by means of external pressure. Chem. - Eur. J. 2018, 24, 7830-7833.

(145) Farney, E. P.; Chapman, S. J.; Swords, W. B.; Torelli, M. D.; Hamers, R. J.; Yoon, T. P. Discovery and elucidation of counteranion dependence in photoredox catalysis. J. Am. Chem. Soc. 2019, 141, 6385-6391.

(146) Rosenthal, J.; Hodgkiss, J. M.; Young, E. R.; Nocera, D. G. Spectroscopic determination of proton position in the proton-coupled electron transfer pathways of donor-acceptor supramolecule assemblies. J. Am. Chem. Soc. 2006, 128, 10474-10483.

(147) Wang, C.; Otto, S.; Dorn, M.; Kreidt, E.; Lebon, J.; Sršan, L.; Di Martino-Fumo, P.; Gerhards, M.; Resch-Genger, U.; Seitz, M.; Heinze, K. Deuterated Molecular Ruby with Record Luminescence Quantum Yield. Angew. Chem., Int. Ed. 2018, 57, 1112-1116.

(148) Ward, M. D. Photo-induced electron and energy transfer in non-covalently bonded supramolecular assemblies. Chem. Soc. Rev. 1997, 26, 365.

(149) Zheng, J.; Swords, W. B.; Jung, H.; Skubi, K. L.; Kidd, J. B.; Meyer, G. J.; Baik, M.-H.; Yoon, T. P. Enantioselective Intermolecular Excited-State Photoreactions Using a Chiral Ir Triplet Sensitizer: Separating Association from Energy Transfer in Asymmetric Photocatalysis. J. Am. Chem. Soc. 2019, 141, 13625-13634.

(150) Wehlin, S. A. M.; Troian-Gautier, L.; Sampaio, R. N.; Marcélis, L.; Meyer, G. J. Ter-Ionic Complex that Forms a Bond Upon Visible Light Absorption. J. Am. Chem. Soc. 2018, 140, 77997802.

(151) Proppe, A. H.; Li, Y. C.; Aspuru-Guzik, A.; Berlinguette, C. P.; Chang, C. J.; Cogdell, R.; Doyle, A. G.; Flick, J.; Gabor, N. M.; van Grondelle, R.; Hammes-Schiffer, S.; Jaffer, S. A.; Kelley, S. O.; Leclerc, M.; Leo, K.; Mallouk, T. E.; Narang, P.; Schlau-Cohen, G. S.; Scholes, G. D.; Vojvodic, A.; Yam, V. W.-W.; Yang, J. Y.; Sargent, E. H. Bioinspiration in light harvesting and catalysis. Nat. Rev. Mater. 2020, $5,828$.

(152) Heinemann, F.; Karges, J.; Gasser, G. Critical Overview of the Use of $\mathrm{Ru}$ (II) Polypyridyl Complexes as Photosensitizers in OnePhoton and Two-Photon Photodynamic Therapy. Acc. Chem. Res. 2017, 50, 2727-2736.

(153) Ardo, S.; Meyer, G. J. Photodriven heterogeneous charge transfer with transition-metal compounds anchored to $\mathrm{TiO}_{2}$ semiconductor surfaces. Chem. Soc. Rev. 2009, 38, 115-164.

(154) Tucker, J. W.; Stephenson, C. R. J. Shining light on photoredox catalysis: theory and synthetic applications. J. Org. Chem. 2012, 77, 1617-1622. 